$\mathbb{1}$

TECHNICAL REPORT

Nordic Green to

Scale for countries

Unlocking the potential of climate solutions in the Baltics, Poland and Ukraine
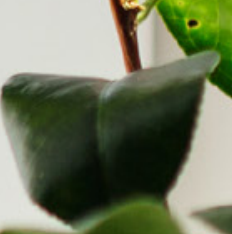



\section{Technical report: Nordic Green to Scale for countries:}

Unlocking the potential of climate solutions in the Baltics, Poland and Ukraine

Lauri Tammiste, Helen Poltimäe, Piret Kuldna, Tiit Kallaste, Kerli Kirsimaa, Olavi Grünvald and Kalle Kuusk

TemaNord 2018:548 
Technical report: Nordic Green to Scale for countries:

Unlocking the potential of climate solutions in the Baltics, Poland and Ukraine

Lauri Tammiste, Helen Poltimäe, Piret Kuldna, Tiit Kallaste, Kerli Kirsimaa, Olavi Grünvald and Kalle Kuusk

ISBN 978-92-893-5847-7 (PRINT)

ISBN 978-92-893-5848-4 (PDF)

ISBN 978-92-893-5849-1 (EPUB)

http://dx.doi.org/10.6027/TN2018-548

TemaNord 2018:548

ISSN 0.908-6692

Standard: PDF/UA-1

ISO 14289-1

(c) Nordic Council of Ministers 2018

Cover photo: iStock by Getty Images

Print: Rosendahls

Printed in Denmark

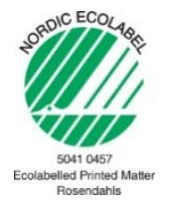

Disclaimer

This publication was funded by the Nordic Council of Ministers. However, the content does not necessarily reflect the Nordic Council of Ministers' views, opinions, attitudes or recommendations.

Rights and permissions

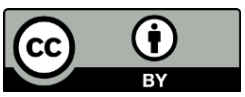

This work is made available under the Creative Commons Attribution 4.0 International license (CC BY 4.0) https://creativecommons.org/licenses/by/4.0

Translations: If you translate this work, please include the following disclaimer: This translation was not produced by the Nordic Council of Ministers and should not be construed as official. The Nordic Council of Ministers cannot be held responsible for the translation or any errors in it.

Adaptations: If you adapt this work, please include the following disclaimer along with the attribution: This is an adaptation of an original work by the Nordic Council of Ministers. Responsibility for the views and opinions expressed in the adaptation rests solely with its author(s). The views and opinions in this adaptation have not been approved by the Nordic Council of Ministers. 
Third-party content: The Nordic Council of Ministers does not necessarily own every single part of this work. The Nordic Council of Ministers cannot, therefore, guarantee that the reuse of third-party content does not infringe the copyright of the third party. If you wish to reuse any third-party content, you bear the risks associated with any such rights violations. You are responsible for determining whether there is a need to obtain permission for the use of third-party content, and if so, for obtaining the relevant permission from the copyright holder. Examples of third-party content may include, but are not limited to, tables, figures or images.

Photo rights (further permission required for reuse):

Any queries regarding rights and licences should be addressed to:

Nordic Council of Ministers/Publication Unit

Ved Stranden 18

DK-1061 Copenhagen K

Denmark

Phone +4533960200

pub@norden.org

\section{Nordic co-operation}

Nordic co-operation is one of the world's most extensive forms of regional collaboration, involving Denmark, Finland, Iceland, Norway, Sweden, and the Faroe Islands, Greenland and Åland.

Nordic co-operation has firm traditions in politics, economics and culture and plays an important role in European and international forums. The Nordic community strives for a strong Nordic Region in a strong Europe.

Nordic co-operation promotes regional interests and values in a global world. The values shared by the Nordic countries help make the region one of the most innovative and competitive in the world.

The Nordic Council of Ministers

Nordens Hus

Ved Stranden 18

DK-1061 Copenhagen K, Denmark

Tel.: +4533960200 www.norden.org

Download Nordic publications at www.norden.org/nordpub 



\section{Content}

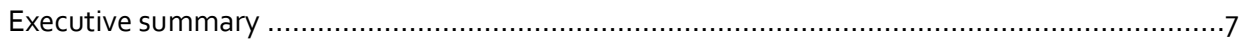

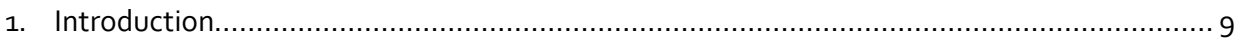

1.1 Green to Scale: concept and background.................................................... 9

1.2 Choice and classification of solutions..........................................................

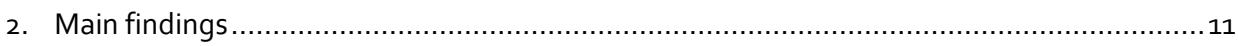

2.1 Greenhouse gas abatement potential and costs ........................................... 11

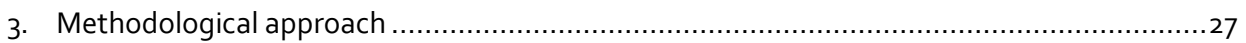

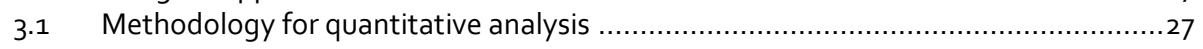

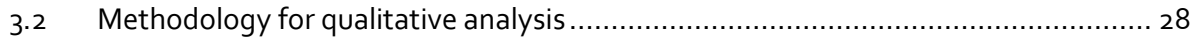

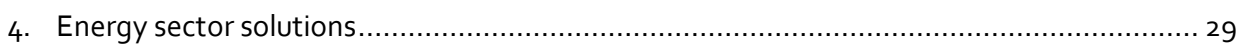

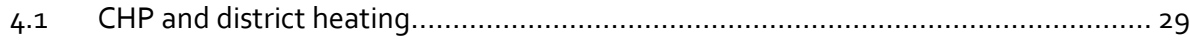

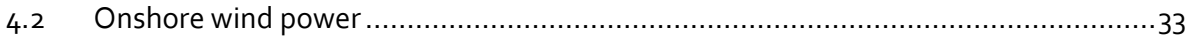

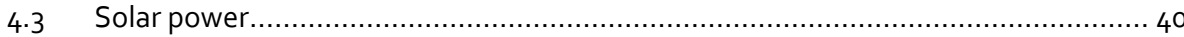

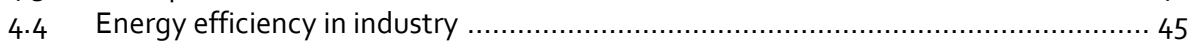

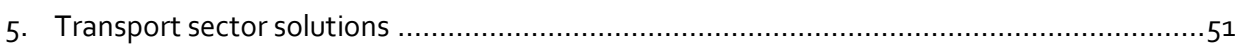

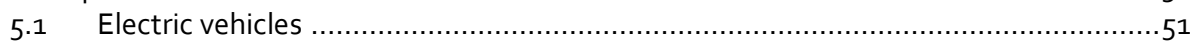

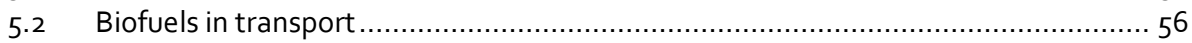

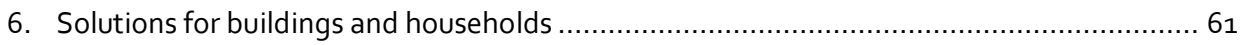

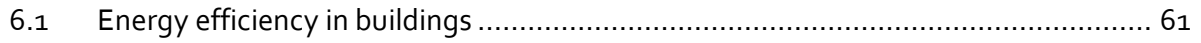

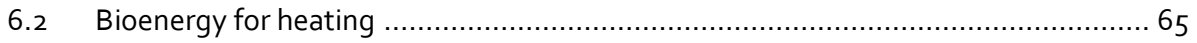

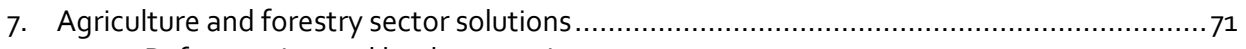

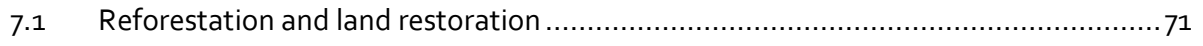

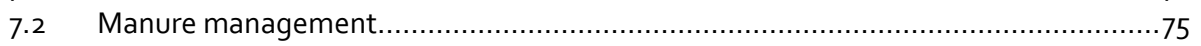

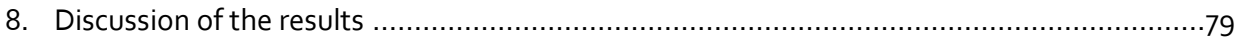

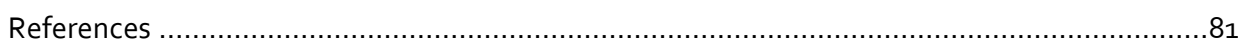

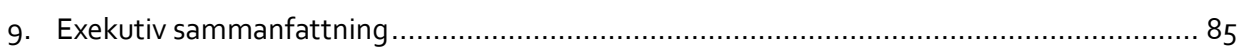

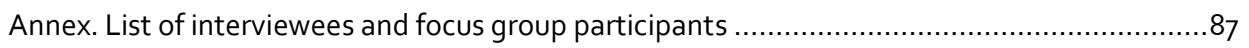




\section{Executive summary}

Nordic Green to Scale 2 (NGtS2) analyses the potential of scaling up existing climate solutions in two regions: the Baltic countries, Poland and Ukraine in Europe; and Kenya and Ethiopia in East Africa. This report reflects the study results for the five European target countries (Estonia, Latvia, Lithuania, Poland and Ukraine). Ten different solutions have been selected out of those included in the two previous studies - Green to Scale ${ }^{1}$ and the Nordic Green to Scale ${ }^{2}$ - as particularly promising for that region.

The analysis covers emission reduction potential, costs and savings as well as cobenefits of scaling up the selected solutions. In addition, the study looks at the countryspecific circumstances for implementing the solutions, including providing policy recommendations tailored to the needs of target countries.

The abatement potential varies greatly between solutions and countries, as the studied countries are of different size, economic structure and development level. If the solutions are implemented together, the abatement potential will be $149 \mathrm{Mt} \mathrm{CO}_{2} \mathrm{eq}$, which forms $13 \%$ of the selected region's GHG emissions by 2030. In absolute values, the highest abatement potential in these countries is related to energy efficiency in buildings and industry ( $53 \mathrm{Mt} \mathrm{CO}_{2}$ eq and $25 \mathrm{Mt} \mathrm{CO}_{2}$ eq respectively). By sector, the highest abatement potential is derived from the buildings and household sector: applying energy efficiency measures and using bioenergy for heating (67 $\mathrm{Mt} \mathrm{CO}_{2}$ eq). The solutions in the energy sector follow, mainly resulting from the abatement potential of onshore wind and solar power development ( $41 \mathrm{Mt} \mathrm{CO}_{2} \mathrm{eq}$ ).

The solutions with highest abatement potential are also the ones that are very costefficient, as their total cost is negative: energy efficiency in buildings would bring net savings of EUR -2.9 billion and energy efficiency in industry would bring net savings of EUR - 0.5 billion by 2030. The unit cost for improved energy efficiency in buildings would be EUR -54 per tonne $\mathrm{CO}_{2}$ eq and EUR - 18 per tonne $\mathrm{CO}_{2}$ eq for improved energy efficiency in industry. The highest costs are with bioenergy for heating (EUR 1 billion), onshore wind (EUR 0.5 billion) and solar power (EUR 0.4 billion).

While for most of the solutions major abatement potential in absolute terms is derived from Poland and Ukraine, in relative terms there is significantly higher impact from scaling up these solutions in Estonia, Latvia and Lithuania. All target countries have good natural resources for the development of wind and solar power as well as of bioenergy. In the European Union (EU) member states, the EU targets, regulations and financial support are of significant importance for enabling the scale-up of the solutions. In Ukraine, international, including EU, agreements and support

${ }^{1}$ Ecofys 2015 by order of: Sitra. Afanador, A., Begemann, E. Bourgault, C., Krabbe, O. Wouters, K. The potential of scaling up proven low-carbon solutions. Final report, 5 November, 2015.

${ }^{2}$ Korsbakken, J. I., Aamaas, B. 2016 Technical report: Nordic Green to Scale. 
programmes aim to promote the similar enabling environment. The ongoing global decline of prices of renewable energy technologies encourages increasingly more developers and consumers to use renewable energy resources. Still the main barriers for the large-scale deployment of the solutions are policies favouring fossil fuel-based economies and uncertainty related with market and legislative development. 


\section{Introduction}

\subsection{Green to Scale: concept and background}

The world is recognizing the inevitable need to deal with climate change. Paris Agreement has set the global target, now it is up to countries, cities and businesses to implement needed reductions. Nordic prime ministers have invited the world to share Nordic knowledge and experiences of Nordic solutions to global challenges as a tool in our common work to reach the United Nations Sustainable Development Goals by the year 2030. The Green to Scale project, as a part of Nordic Climate Solutions, has highlighted the potential of scaling up existing ways of solving the climate problem. In 2015, the project looked at 17 solutions from five different sectors, both from the global North and South. In total, the 17 global solutions would cut annual greenhouse gases, measured in carbon dioxide equivalent $\left(\mathrm{CO}_{2} \mathrm{eq}\right)$, by 9 billion tonnes (gigatonnes, $\mathrm{Gt}$ ) by 2025 and by $12 \mathrm{Gt}$ in 2030. These reductions are significant: $12 \mathrm{Gt}$ is equivalent to nearly a quarter of annual global emissions at present.

In 2016, the Nordic Green to Scale project focused on 15 Nordic solutions ranging from wind power to electric vehicles. Scaling up the selected Nordic solutions could cut global emissions by 4.1 gigatonnes ( $\mathrm{GtCO}_{2} \mathrm{eq}$ ) in 2030. The reduction would be equal to the current total emissions of the European Union. The net cost of implementing all 15 solutions was estimated to be USD 13 billion in 2030. To put the costs into perspective, scaling up the solutions would equal what countries globally spend on fossil fuel subsidies in just nine days.

Previous phases have uncovered a vast emission reduction potential by using proven solutions which are readily available and already deployed somewhere around the world. Scaling up these solutions would be in most cases affordable and provide significant benefits to people and the environment. To reap the emission reduction potential, countries would need to reach the same level of diffusion of these solutions as others already have.

However, there is a long way from highlighting a potential at a global scale to deploying the solutions in practice in different jurisdictions. That is why this phase of Green to Scale zooms in on selected countries, moving a level closer to implementation.

Nordic Council of Ministers (NCM) has financially supported and the NCM Climate and Air Pollution group has served as the advisory council for the project. The Finnish Innovation Fund Sitra has hosted the project secretariat. CONCITO (Denmark), CICERO (Norway) and University of Iceland were members of the steering group. For more information on the project and the previous two phases, please refer to www.greentoscale.net.

The work for the European countries was carried out by a consortium of four institutions: SEI Tallinn Centre (the service provider and consortium leader), Institute of Physical Energetics, Latvia, Lithuanian Energy Institute, and Institute for Environment and Energy Conservation, Ukraine. The analysis of the selected solutions consists of: 
- Potential emissions reductions, costs and savings;

- Enablers for and barriers to applying the solutions;

- Co-benefits of their implementation; and

- Policy recommendations for efficient adoption of feasible solutions.

\subsection{Choice and classification of solutions}

The selection of the solutions was done in consultation with experts in the target countries and the steering group based on the following criteria:

- Alignment with challenges identified in national energy and climate strategies;

- Current penetration and potential scalability based on suitability of a solution to the countries in question;

- Balanced representation of different sectors (energy, transport, buildings and households, industry, forestry and agriculture).

The following 10 solutions were selected for the study. The countries in the brackets were used as reference countries for the implementation of the respective solution, as described in the global Green to Scale report (Ecofys, 2015) and in the Nordic Green to Scale report (Korsbakken \& Aamaas, 2016):

Energy sector solutions:

1. Combined Heat and Power (CHP) and district heating (Finland)

2. Onshore wind power (Sweden and Denmark)

3. Solar power (Germany)

Industrial sector solutions:

4. Energy efficiency in industries (China)

Transport sector solutions:

5. Electric vehicles (Norway)

6. Liquid biofuels in transport (Sweden)

Buildings and household sector solutions:

7. Energy efficiency in buildings (Sweden)

8. Bioenergy for heating (Finland)

Agriculture and forestry solutions:

9. Reforestation and land restoration (Iceland)

10. Manure management (Denmark) 


\section{Main findings}

\subsection{Greenhouse gas abatement potential and costs}

The abatement potential in the studied five countries is presented in Figure 1 in absolute terms ( $\mathrm{Mt} \mathrm{CO}_{2}$ eq). Looking at the abatement potential as a share of the studied five countries' GHG emissions, it can be seen that no single solution alone can work to decrease the emission level drastically, as the current total GHG emissions for

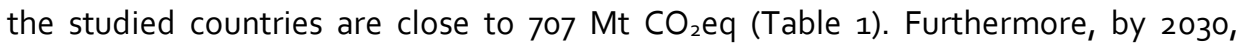
without action the GHG emissions are expected to further increase in these countries: in total these are projected to be $1,110 \mathrm{Mt} \mathrm{CO}_{2}$ eq (European Commission 2016; Factor $\mathrm{CO}_{2}$ 2011). Due to this increase, the effect of individual solutions in terms of abatement is not very large (up to $5 \%$ ). However, if implemented together, the abatement potential would be $149 \mathrm{MtCO}_{2}$ eq, which forms $13 \%$ of regional GHG emissions by 2030 . This potential of different solutions is very country-specific; therefore the results are presented also by country in the next sections. It is also worthwhile to stress that the abatement potential presented in this report is additional, in the sense that it represents what could be achieved additional to currently implemented and planned policy measures (European Environment Agency 2017).

In absolute values, the highest abatement potential in these countries is related to energy efficiency: applying energy efficiency measures in buildings would result in a decrease of $53 \mathrm{Mt} \mathrm{CO}_{2}$ eq by 2030 and energy efficiency in industry would result in a decrease of about $25 \mathrm{Mt} \mathrm{CO}_{2}$ eq. Most of this energy efficiency related abatement potential originates from Poland and Ukraine. If looking at the Baltic countries (Estonia, Latvia and Lithuania), onshore wind has the highest abatement potential: $12 \%$ of net GHG emissions in 2030 in Estonia, 14\% in Latvia and $16 \%$ in Lithuania. In relative terms, these percentages are the highest abatement potential in the studied countries. Hence, the big amounts in absolute terms do not necessarily mean high potential in relative terms and vice versa.

The different coloured bars in Figure 1 represent the solutions by sector. As can be seen, the highest abatement potential is derived from the buildings and household sector: together these would amount to about $67 \mathrm{Mt} \mathrm{CO}_{2}$ eq. The energy sector solutions would present abatement potential of about $41 \mathrm{MtCO}_{2} \mathrm{eq}$, mainly resulting from onshore wind and solar power. In the studied five countries onshore wind, which can provide the biggest impact in the Baltics, has an abatement potential close to $20 \mathrm{Mt} \mathrm{CO}_{2}$ eq in total, solar power $17 \mathrm{Mt} \mathrm{CO}{ }_{2}$ eq and bioenergy for heating about $1_{4} \mathrm{Mt} \mathrm{CO}_{2}$ eq.

Industry-related solutions would also bring quite substantial abatement potential, and this is related to a single solution: energy efficiency in industry ( $25 \mathrm{Mt} \mathrm{CO}_{2}$ eq). The transport sector and the agriculture and forestry sector would provide $10 \mathrm{MtCO}_{2} \mathrm{eq}$ and $6 \mathrm{Mt} \mathrm{CO}_{2}$ eq abatement potentials respectively. 
Not all solutions were applicable to all countries: for example, combined heat and power (CHP) abatement potential was not assessed for Poland and Latvia (for neither industries nor urban district heating) and in Ukraine for industries, as the current share of CHP already exceeds the benchmark level. Also, bioenergy for heating was not applicable for the Baltic countries for the same reason.

Figure 1: Abatement potential of different solutions by 2030, in total for Estonia, Latvia, Lithuania, Poland and Ukraine ( $\left.\mathrm{Mt} \mathrm{CO}_{2} \mathrm{eq}\right)$

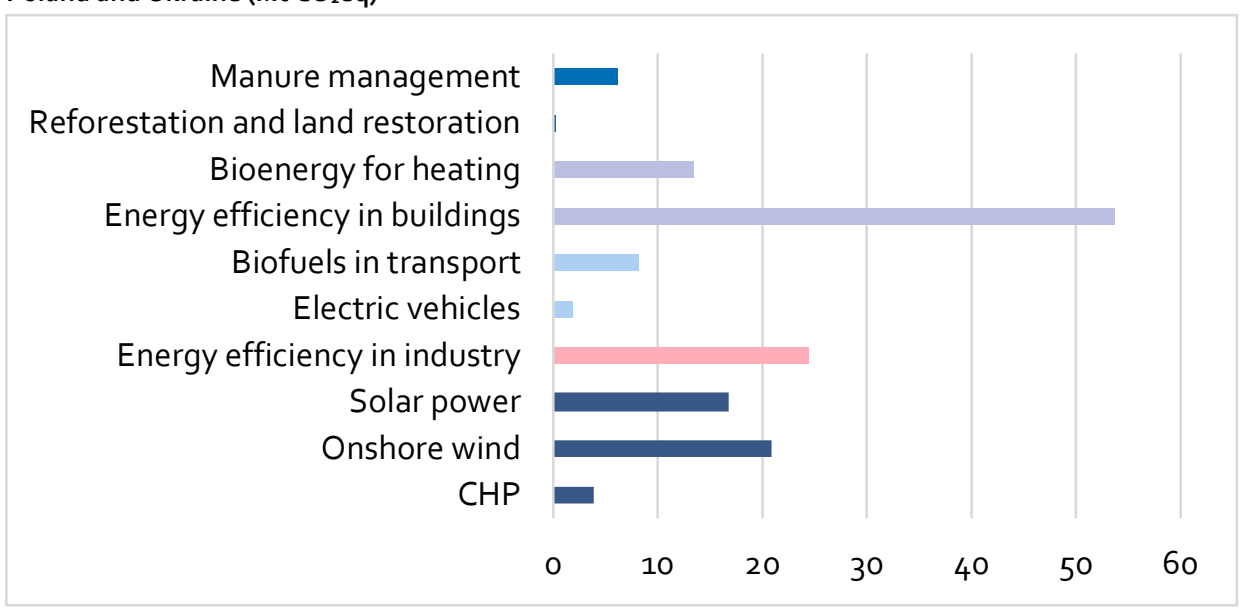

In addition to the abatement potential, the cost is an important factor to consider. Figure 2 shows that the solutions with highest abatement potential are also the ones that are very cost-efficient, as their total cost is negative: energy efficiency in buildings would bring net savings of EUR -2.9 billion and energy efficiency in industry would bring net savings of EUR -0.5 billion by 2030. That means that the reduced energy consumption and the concurrent savings are larger than the costs necessary to achieve this.

For each of the other solutions, the total costs are positive. The highest costs are with bioenergy for heating (EUR 1 billion), onshore wind (EUR 0.5 billion) and solar power (EUR 0.4 billion). However, these solutions' abatement potential is also relatively high compared to other solutions. The total cost of electric vehicles is close to EUR 200 million, but this is due to a substantially higher unit cost of electric vehicles, the abatement potential of this solution is not very high. 
Figure 2: Abatement costs of different solutions by 2030, in total for Estonia, Latvia, Lithuania, Poland and Ukraine (million EUR)*

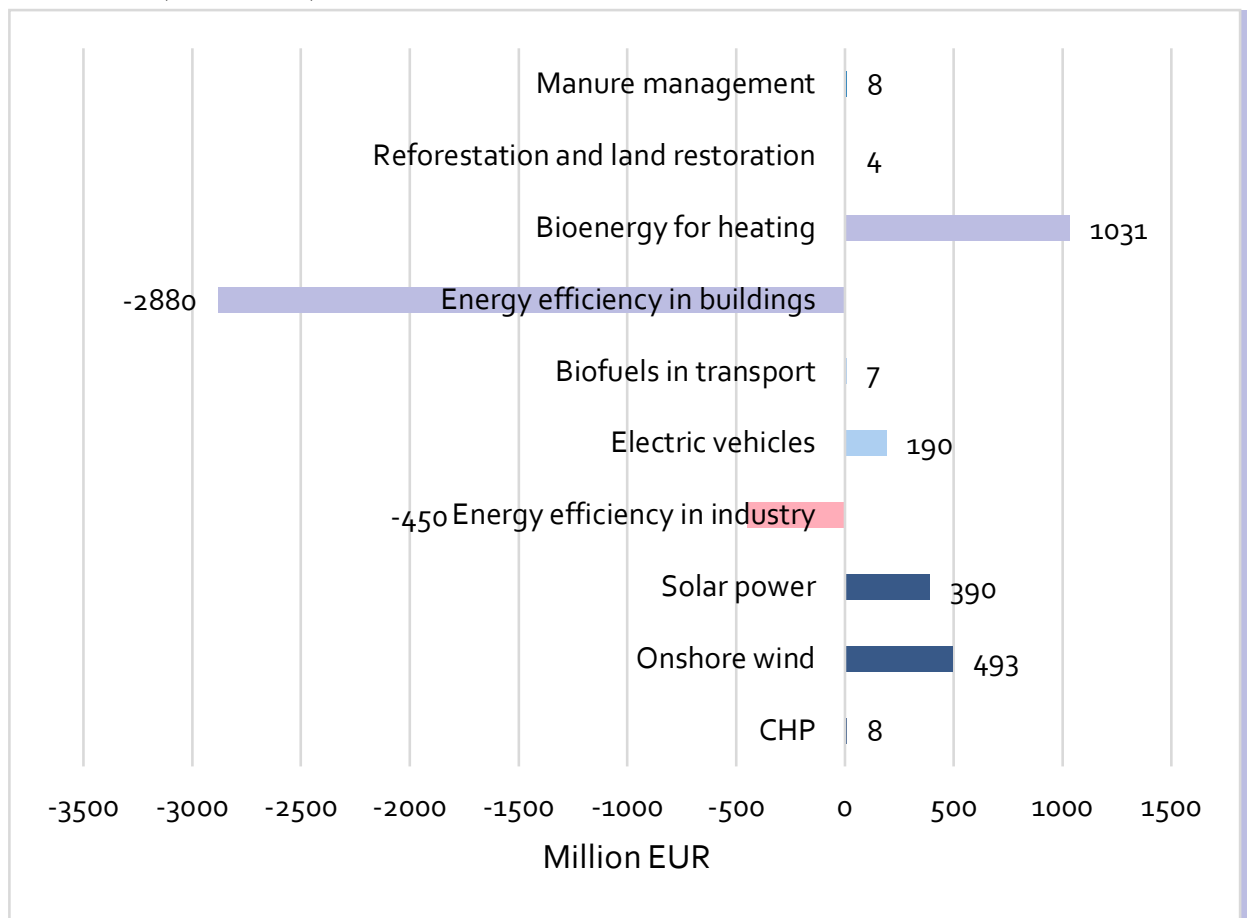

Note: * If solution comprises different parts or solutions, weighted average cost has been presented in the Figure.

The unit costs are the highest for electric vehicles (104 EUR/t $\mathrm{CO}_{2}$ eq) and bioenergy for heating (77 EUR/t $\mathrm{CO}_{2}$ eq). Solar power, onshore wind and reforestation would each cost about EUR 20 per tonne $\mathrm{CO}_{2}$ eq. As is discussed above, the most costefficient solutions are related to energy efficiency: the unit cost for improved energy efficiency in buildings would be EUR -54 per tonne $\mathrm{CO}_{2}$ eq and EUR - 18 per tonne $\mathrm{CO}_{2}$ eq for improved energy efficiency in industry. The unit costs are presented in Figure 3. 


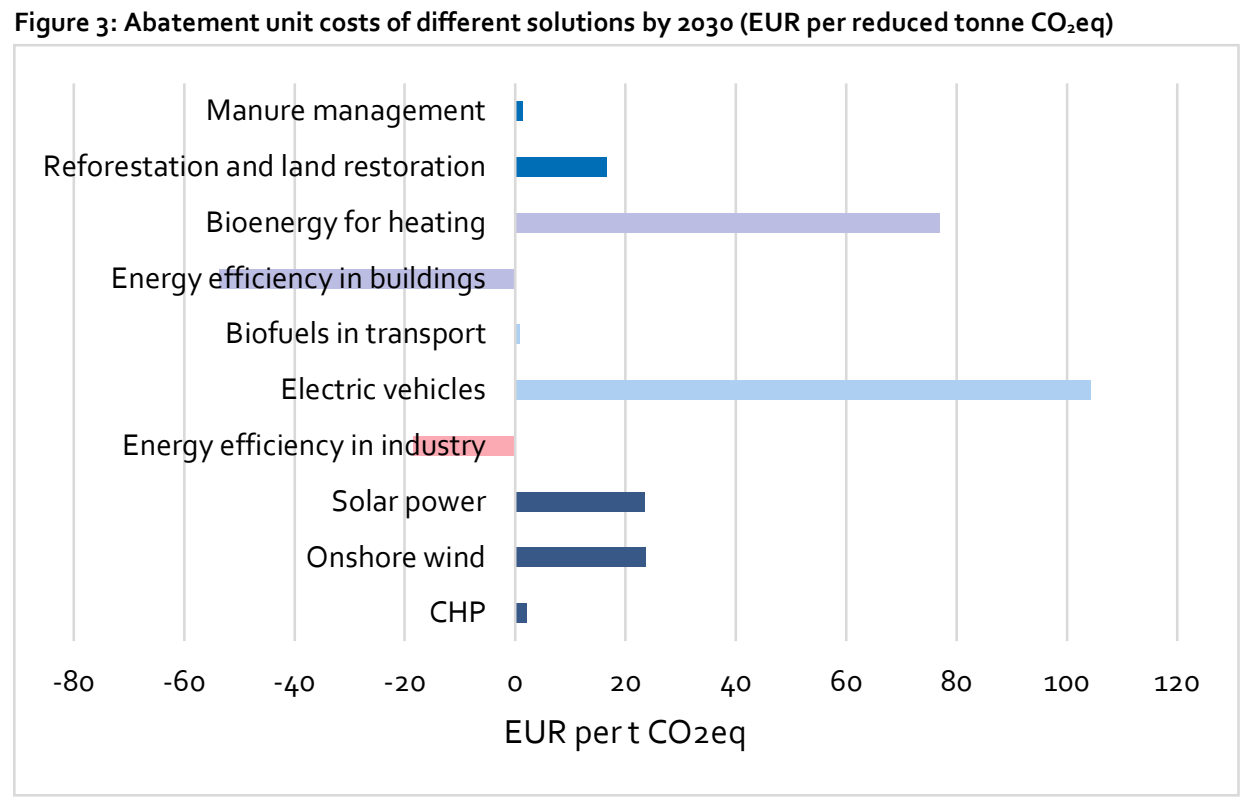

Note: * If solution comprises different parts or solutions, weighted average cost figure has been presented in the Figure.

For most of the solutions, major abatement potential in absolute terms is derived from Poland and Ukraine, and is largely related to the size of population and economy. As shown in Table 1, Poland and Ukraine are about 20 times larger than each of the Baltic countries in terms of population and about 5-10 times larger in terms of land area. This fact has implications on the abatement potential.

However, in relative terms there is significantly higher impact from scaling up these solutions in Estonia, Latvia and Lithuania, because the total additional abatement potential as a share of 2030 expected emissions would be $40 \%, 30 \%$ and $30 \%$ respectively compared to $19 \%$ in Poland and $9 \%$ in Ukraine. The countries differ in terms of development: while in Estonia GDP per capita is about 17 thousand USD, in Ukraine it is about 2 thousand USD. All of the countries studied fall below the EU average in terms of development measured by GDP per capita (32,233 USD in 2016) (World Bank, 2018). As the current development levels differ, the development paths of the near future also differ. This has implications on baseline assumptions (for example, change in private motorization, housing stock, etc).

In terms of GHG emissions, larger countries are larger emitters: in 2015, Poland emitted $357 \mathrm{MtCO}_{2}$ eq and Ukraine $309 \mathrm{Mt} \mathrm{CO}$ eq (Table 1). From the per capita perspective, Estonia is the largest emitter: 15 metric tonnes per capita. All of the other countries have significantly lower per capita figures, ranging from 3.5 metric tonnes for Latvia to 7.5 metric tonnes for Poland. Looking at the baselines of GHG emissions by 2030, an increase of emissions has been projected compared to 2015 level for three countries: in Lithuania these are projected to increase by $30 \%$, in Poland $5 \%$ and in Ukraine a twofold increase has been projected (European Commission 2016; Factor $\mathrm{CO}_{2}$ 2011). For Estonia and Latvia, a slight decrease has been estimated: $-10 \%$ and $-20 \%$ respectively (European Commission 2016). 
Socio-economic data

\begin{tabular}{|c|c|c|c|c|c|}
\hline GDP (million USD) & 23,337 & 27,572 & 42,739 & 471,364 & 93,270 \\
\hline GDP per capita (USD) & 17,728 & 14,065 & 14,879 & 12,421 & 2,185 \\
\hline $\begin{array}{l}\text { GDP per capita (index, EU } \\
\text { average }=100 \text { ) }\end{array}$ & 55 & 44 & 46 & 39 & 7 \\
\hline Population (thousand) & 1,317 & 1,960 & 2,872 & 37,948 & $45,005^{*}$ \\
\hline Land area (sq.km) & 42,390 & 62,180 & 62,650 & 306,190 & $579,290 *$ \\
\hline \multicolumn{6}{|l|}{ Greenhouse gas emissions } \\
\hline $\begin{array}{l}\text { GHG emissions, with LULUCF** } \\
\left(\mathrm{Mt} \mathrm{CO}_{2} \text { eq) }\right.\end{array}$ & $15 \cdot 7$ & 12.7 & 13.4 & 357 & 308.6 \\
\hline $\begin{array}{l}\mathrm{CO}_{2} \text { emissions, metric tonnes per } \\
\text { capita }\end{array}$ & 14.8 & $3 \cdot 5$ & 4.4 & 7.5 & 5.0 \\
\hline $\begin{array}{l}\mathrm{CO}_{2} \text { intensity of solid fuel } \\
\text { consumption, } \mathrm{kg} \text { per } \mathrm{kg} \text { of oil } \\
\text { equivalent energy use }\end{array}$ & 3.2 & 1.6 & 1.8 & 3.0 & 2.2 \\
\hline $\begin{array}{l}\mathrm{CO}_{2} \text { emissions, } \mathrm{kg} \text { per USD of } \\
\text { GDP }\end{array}$ & 0.9 & 0.3 & 0.3 & 0.5 & 1.7 \\
\hline \multicolumn{6}{|l|}{ Renewable energy } \\
\hline $\begin{array}{l}\text { Total renewable energy capacity } \\
\text { (MW) }\end{array}$ & 619 & 1,787 & 757 & 7,930 & 6,225 \\
\hline Incl. wind (MW) & 310 & 69 & 493 & 5,807 & 525 \\
\hline Incl. solar photovoltaic (MW) & 11 & 3 & 71 & 99 & 938 \\
\hline
\end{tabular}

Note: * The World Bank data exclude Autonomous Republic of Crimea, the population of which is $2,018,400$ and territory $26,100 \mathrm{~km}^{2}$ (Ministry of Foreign Affairs of Ukraine, website).

** Land use, land use-change and forestry.

Source: Data for GHG emissions: UNFCCC 2018, data on renewable energy: IRENA 2017, other data: World Bank 2018.

Looking at single solutions and the roles of different countries in the total abatement potential, Poland's share ranges from $15 \%$, in case of onshore wind, up to $70 \%$, in case of bioenergy for heating. For Ukraine, the share in total abatement potential ranges from $23 \%$, in case of energy efficiency in industry, up to $97 \%$ in case of combined heat and power (CHP). The role of the Baltic countries in the total abatement of the region is small in absolute numbers, but their share in GHG emissions is also low. The abatement potential of different solutions in relation to specific country emissions is provided in the next subsections.

In general, the main abatement potential comes from energy efficiency measures, which are also highly cost-efficient. However, apart from energy efficiency measures, the pattern in different countries is more mixed. For the Baltic countries, energy sector solutions, specifically onshore wind, have relatively high potential. For Poland and Ukraine, there is significant abatement potential in 
solutions for buildings and households. Among the studied solutions, reforestation and electric vehicles are solutions with the least abatement potential. The main results by the studied countries are provided below.

\subsubsection{Estonia}

\section{Country profile}

Estonian GHG emissions were close to $40 \mathrm{Mt} \mathrm{CO}_{2}$ eq in 1990 (with LULUCF${ }^{3}$ ), but fell considerably after gaining independence from Soviet Union: by 1993 the emissions level was about $20 \mathrm{Mt} \mathrm{CO}_{2}$ eq (Estonian National Inventory Report, 2017). In 2015, the emissions level was about $15 \mathrm{Mt} \mathrm{CO}_{2}$ eq (Estonian National Inventory Report, 2017), and it is expected to further decrease in the future: by 2030 it is projected to $13.7 \mathrm{MtCO}_{2} \mathrm{eq}$ (European Commission, 2016). The Nationally Determined Contribution of the EU and its member states is a targeted reduction of at least $40 \%$ in GHG emissions by 2030 compared to 1990 (Submission by Latvia, 2015). In addition to that, similarly to other EU member states, Estonia is participating in Emission Trading System, has binding targets for $\mathrm{CO}_{2}$ in non-ETS sectors and is bound by EU LULUCF regulation.

As of 2016, the share of renewable energy used in final consumption in Estonia was $28.8 \%$. The share of renewable energy sources (RES) in the heating and cooling sector was $51.2 \%$, in the electricity sector $15.5 \%$ and in transport $0.4 \%$ (Eurostat).

The renewable energy targets by 2020 for $25 \%$ of final energy consumption and $38 \%$ for heating and cooling have already been achieved, but the respective targets for electricity generation (17.6\%) and transport (10\%) have not yet been reached (REN21, 2017).

According to the National Development Plan of the Energy Sector until 2030, the share of renewable energies shall increase to $50 \%$ of final energy consumption, the share of renewable energy sources shall account for $80 \%$ of the heat generated in Estonia and $50 \%$ of final consumption of domestic electricity by 2030 .

To date, Estonian energy system is still extensively based on oil shale. From renewable energy sources, wind power capacity accounted for $65 \%$ of the installed capacity of renewable energy by the end of 2016. However, due to various restrictions, it would be more probable that the next large wind farms will be built offshore in Estonia. The share of biomass production capacities by electricity generation was $25 \%$ and the share of solar PV capacities 2.3\% (EREA, 2017). In particular, there has been a fast growth of solar photovoltaic installations both by private persons and enterprises (in 2011 - the installed capacity was $0.2 \mathrm{MW}$, in 2016 - 11 MW, plus offgrid generation) (ibid.). Another $10 \mathrm{MW}$ capacity is under the development by the state-owned energy utility company AS Eesti Energia, who also continues to utilise oil shale.

3 Here and in the following sections: GHG emissions of the countries are provided with LULUCF. 
Findings

The total abatement potential of these solutions would be about $5 \mathrm{Mt} \mathrm{CO}_{2}$ eq by 2030 . Analysing it in the context of Estonian net GHG emissions projected for that timeframe (about $13 \mathrm{Mt} \mathrm{CO}_{2} \mathrm{eq}$ ), these solutions would amount to a reduction potential of around $40 \%$ of 2030 emission levels.

The solution with the highest potential for Estonia is onshore wind (1.7 $\mathrm{Mt} \mathrm{CO}_{2} \mathrm{eq}$ ), followed by energy efficiency measures in industry and buildings ( 1.4 and $1.3 \mathrm{Mt} \mathrm{CO}_{2}$ eq respectively) (see Figure 4). Taking into account the projected net GHG emissions of Estonia by 2030 , these three top solutions would decrease the $2030 \mathrm{GHG}$ emissions by 9-12\% each. Energy efficiency in buildings would decrease GHG emissions by $8 \%$, energy efficiency in industry by $9 \%$ and onshore wind by $12 \%$.

Apart from the three solutions of the highest potential, the rest of these have much lower potential, ranging from $0.02 \mathrm{Mt} \mathrm{CO}_{2}$ eq for reforestation and land restoration up to $0.4 \mathrm{Mt} \mathrm{CO}_{2}$ eq for solar. From the sector perspective, the energy sector solutions would bring the largest reduction in GHG emissions (about $2 \mathrm{Mt}$ $\mathrm{CO}_{2}$ eq) in Estonia.

Figure 4: Abatement potential of different solutions by 2030, Estonia $\left(\mathrm{Mt} \mathrm{CO}_{2} \mathrm{eq}\right.$ and $\%$ of 2030 emissions)*

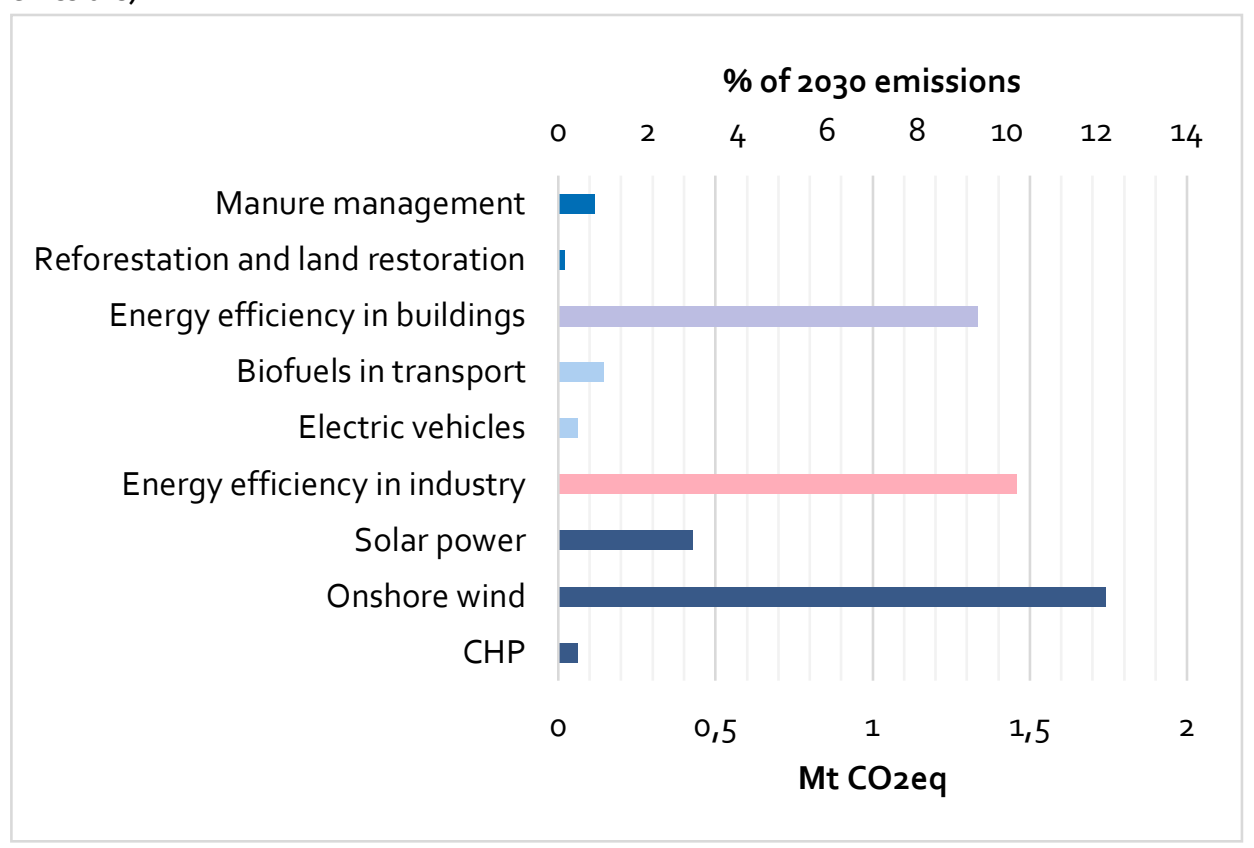

Note: * As Estonia is above benchmark for bioenergy for heating, this solution is not presented in the Figure. 
Key recommendations for the solutions with highest potential

Given the greatest abatement potential of onshore wind, agreement on the long-term goals and measures for wind energy is needed in order to ensure stable legal and investment framework.

It might be useful to consider bidding system for onshore wind projects and to make sure that there are no administrative or technical barriers for wind power development. Investments into grid reinforcement and modernisation and supporting connection to network are also needed. Open dialogue with affected community members is recommended from the outset of wind park siting to minimize the environmental impacts of wind power generation and to plan local community benefits.

On energy efficiency in industries and buildings, a combination of financial incentives, such as investment grants, tax credits, leasing models, and capacity building can tap into the potential of these solutions. Strengthening the advisory system is useful in order to reach out to apartment associations and homeowners with less know-how and skills.

\subsubsection{Latvia}

\section{Country profile}

In Latvia, GHG emissions were $17 \mathrm{Mt} \mathrm{CO}_{2}$ eq in 1990. Similar to Estonia, the emissions decreased in Latvia significantly in the beginning of 1990 , reaching the minimum level of less than $3 \mathrm{Mt} \mathrm{CO}_{2}$ eq by 1996 (Latvia's National Inventory Report, 2017). In 2015, the emissions level was $12.7 \mathrm{Mt} \mathrm{CO}_{2}$ eq (Latvia's National Inventory Report, 2017), and it is expected to slightly decrease in the future. By 2030 it is projected to be $10.1 \mathrm{Mt} \mathrm{CO}_{2}$ eq (European Commission, 2016). The Nationally Determined Contribution of the $\mathrm{EU}$ and its member states is targeted reduction of at least $40 \%$ in GHG emissions by 2030 compared to 1990 (Submission by Latvia, 2015). In addition to that, similarly to other EU member states, Latvia is participating in Emission Trading System, has binding targets for $\mathrm{CO}_{2}$ in non-ETS sectors and is bound by EU LULUCF regulation.

As of 2016, the share of renewable energy used in final consumption in Latvia was $37.2 \%$ (third highest in the EU). The share of renewable energy in heating and cooling was $51.9 \%$, in electricity $51.3 \%$ and in the transport sector $2.8 \%$ (Eurostat).

By $2020,40 \%$ final energy consumption has to come from the renewable energy sources. The share of energy from renewable sources in heating and cooling by the same time shall be $53.4 \%$, in electricity generation $60 \%$ and in transport $10 \%$ (REN21, 2017). In 2013, Latvia approved its Long-Term Energy Strategy up to 2030, but ambitious long-term renewable energy targets are still to be set.

Latvia is dependent on imports for its primary energy resources. Lacking fossil resources, Latvia has a high level of import dependency on oil and gas. Hydropower and gas provide most of the domestic supply of electricity, with wind and, especially, biomass contributing to the energy mix in recent years (LIAA, 2015).

In terms of Latvian renewable energy capacity, hydropower prevails: its three large hydropower plants have an average production of approximately $2.8 \mathrm{TWh}$ (over 1,500 MW of capacity). In 2016, this formed $52 \%$ of overall electricity generated by Latvenergo Group who provides $74 \%$ of all electricity generated in the 
country. Thus the share of hydropower is $44 \%$ in Latvia's electricity generation. In the onshore wind and solar photovoltaic sectors the installed capacities have remained at a similar level over the last few years: respectively $69 \mathrm{MW}$ and 2-3 MW (IRENA, 2017).

\section{Findings}

The abatement potential of different solutions in Latvia is altogether about $3.4 \mathrm{Mt}$ $\mathrm{CO}_{2}$ eq (Figure 5). Analysing the solutions' abatement potential in the context of Latvian projected GHG emissions by 2030 ( $10 \mathrm{Mt} \mathrm{CO}_{2}$ eq), these solutions would substantially help to decrease the level of net GHG emissions by about 30\% (2.9 $\mathrm{Mt} \mathrm{CO}_{2}$ eq) in total of projected net GHG emissions in 2030.

Similar to Estonia, onshore wind has the highest abatement potential in Latvia (1.4 $\mathrm{Mt} \mathrm{CO}_{2}$ eq), followed by energy efficiency in buildings ( $0.7 \mathrm{Mt} \mathrm{CO}_{2} \mathrm{eq}$ ). The rest of the solutions each have abatement potential of $0.3 \mathrm{Mt} \mathrm{CO}_{2}$ eq or less. The solutions with the lowest potential are reforestation and land restoration and electric vehicles ( 0.03 and 0.07 $\mathrm{Mt} \mathrm{CO}_{2}$ eq correspondingly). From the sector perspective, the energy sector solutions are

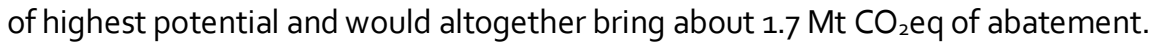

Putting the abatement potential of solutions into the context of Latvian projected net GHG emissions by 2030, the different solutions would decrease the projected total by up to $14 \%$ each. As already discussed above, onshore wind is the solution with highest abatement potential ( $14 \%$ of projected GHG emissions by 2030). The other solutions have abatement potential of $2 \%$ in case of biofuels in transport, $3 \%$ in case of solar power, manure management and energy efficiency each, and $7 \%$ in case of energy efficiency in buildings. Energy efficiency solutions are the most cost-efficient.

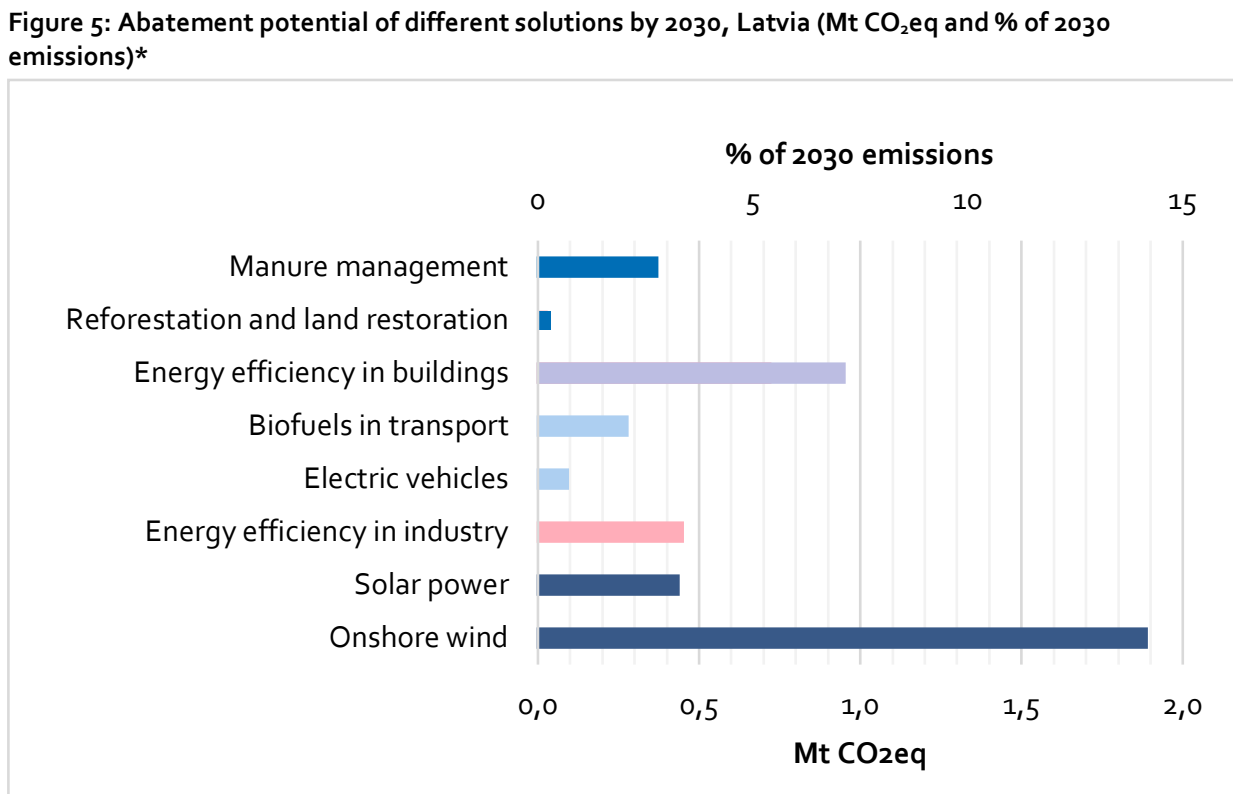

Note: * As Latvia is above benchmark for CHP and bioenergy for heating, these solutions are not presented in the Figure. 


\section{Key recommendations for the solutions with highest potential}

As the wind sector is the solution with highest abatement potential in Latvia, agreement on the longterm goals and measures for renewable energy is needed in order to ensure stable legal and investment framework.

It might be useful to consider a bidding system for onshore wind projects and to make sure that there are no administrative or technical barriers for wind power development. Investments into grid reinforcement and modernisation and supporting connection to network are also needed. Open dialogue with affected community members is recommended from the outset of wind park siting to minimize the environmental impacts of wind power generation and to plan local community benefits.

For realising the potential of energy efficiency in buildings, financial incentives have proven to be useful. Instruments to promote better self-organisation of inhabitants may be needed for multiapartment buildings, e.g. via mandatory apartment associations in order to form legal body for managing the negotiations, financial resources and construction works related to renovation. This has to be accompanied by a strong advisory system in order to reach out to apartment associations and homeowners with less know-how and skills.

\subsubsection{Lithuania}

\section{Country profile}

GHG emissions were $45 \mathrm{MtCO}_{2}$ eq in 1990 in Lithuania and decreased to $20 \mathrm{Mt} \mathrm{CO}_{2}$ eq by 1993 (Lithuania's National Inventory Report, 2017). In 2015, the emissions level was about $13.4 \mathrm{MtCO}_{2}$ eq (Lithuania's National Inventory Report, 2017), and it is expected to increase to $17.2 \mathrm{Mt} \mathrm{CO}{ }_{2}$ eq by 2030 (European Commission, 2016). The Nationally Determined Contribution of the EU and its member states is targeted $40 \%$ reduction in $\mathrm{GHG}$ emissions by 2030 compared to 1990 (Submission by Latvia, 2015). In addition to that, similarly to other EU member states, Lithuania is participating in Emission Trading System, has binding targets for $\mathrm{CO}_{2}$ in non-ETS sectors and is bound by EU LULUCF regulation.

As of 2016, the share of renewable energy used in final consumption in Lithuania was $25.6 \%$. The share of renewable energy in heating and cooling was $46.5 \%$, in electricity $16.8 \%$ and in transport 3.6\% (Eurostat).

The renewable energy targets for 2020 are exceeded in the final energy consumption (23\%) and in heating and cooling (39\%). The renewable energy target for 2020 is $21 \%$ for electricity generation and $10 \%$ for transportation energy (REN21, 2017).

Ambitious renewable energy targets for 2050 are set in the updated national energy strategy, which is to be yet approved by the Parliament, as of March 2018. The share of renewable energy in the gross final energy demand is foreseen to be $30 \%$ in $2020,45 \%$ in 2030 and $80 \%$ in 2050 . The same share of renewables is planned for electricity generation: $30 \%$ in 2020, $45 \%$ in 2030 and $80 \%$ in 2050 .

The installed onshore wind energy capacities have grown rapidly. In the last three years the figures are as follows: $288 \mathrm{MW}$ in 2014, $436 \mathrm{MW}$ in 2015, $493 \mathrm{MW}$ in 2016 (IRENA, 2017). The feed-in tariff system has significantly contributed to this. The installed solar power capacity per year has been stable during the last years with no additional development from the roughly $70 \mathrm{MW}$ capacity level (ibid.). Still, there is a high potential for further increase as the price of photovoltaics has dropped. 
Findings

Implemented together, the different solutions would bring about a $5 \mathrm{Mt} \mathrm{CO}_{2}$ eq abatement potential for Lithuania, which forms $30 \%$ of the country's projected net GHG emissions by 2030 (Figure 6).

By far, the most promising solution is onshore wind, which has the abatement potential of $2.8 \mathrm{Mt} \mathrm{CO}_{2}$ eq by 2030. All the rest of solutions would each give less than $1 \mathrm{Mt} \mathrm{CO}_{2}$ eq as abatement potential. Energy efficiency in industry would decrease GHG emissions by $0.6 \mathrm{Mt} \mathrm{CO}_{2} \mathrm{eq}_{i}$ solar power $0.6 \mathrm{Mt} \mathrm{CO}_{2}$ eq and manure management $0.4 \mathrm{Mt} \mathrm{CO}_{2}$ eq.

Lithuania's yearly greenhouse gas emissions are projected to be $17 \mathrm{Mt} \mathrm{CO}_{2}$ eq in 2030. Hence the abatement potential of the assessed solutions as a share of 2030 net GHG emissions is $2 \%$ for biofuels in transport and energy efficiency in buildings, $3 \%$ for manure management and solar power, $4 \%$ for energy efficiency in industry and close to $17 \%$ for onshore wind.

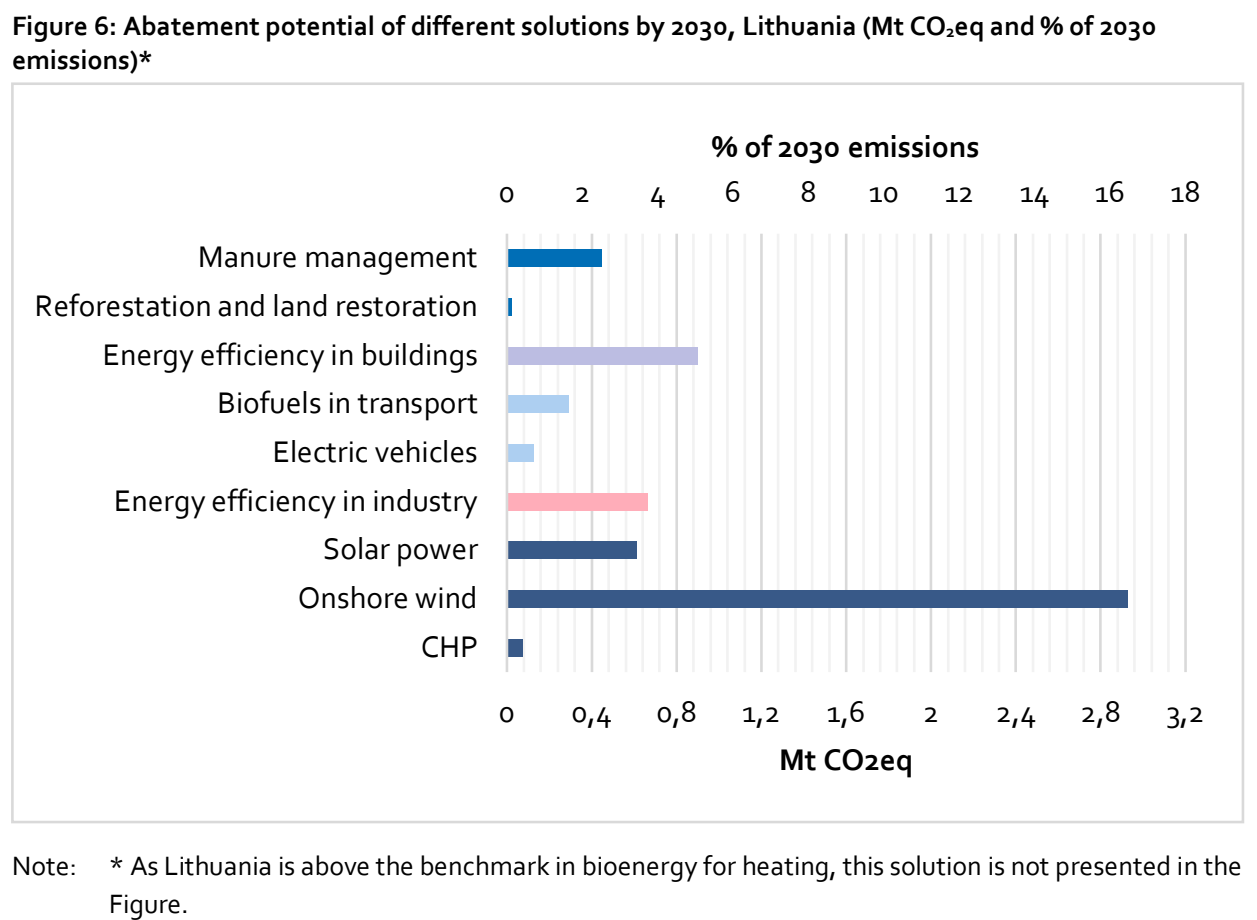




\section{Key recommendations for the solutions with highest potential}

Given the greatest abatement potential of onshore wind, agreement on the long-term measures for wind energy is needed in order to ensure a stable legal and investment framework.

It might be also useful to make sure that there are no administrative or technical barriers for wind power development. Investments into grid reinforcement and modernisation and support connection to network are also needed. Open dialogue with affected community members is recommended from the outset of wind park siting to minimize the environmental impacts of wind power generation and to plan local community benefits.

For realising the potential of energy efficiency in buildings, financial incentives have proven to be useful. Instruments to promote better self-organisation of inhabitants may be needed for multiapartment buildings, e.g. via mandatory apartment associations in order to form legal body for managing the negotiations, financial resources and construction works related to renovation. This has to be accompanied by a strong advisory system in order to reach out to apartment associations and homeowners with less know-how and skills.

\subsubsection{Poland}

\section{Country profile}

As Poland is a much larger country, compared to the Baltic states, the GHG emissions level is also substantially higher: in 1990 they were $442 \mathrm{Mt} \mathrm{CO}_{2}$ eq (Poland's National Inventory Report, 2017). In 2015, the emissions level was 357 Mt $\mathrm{CO}_{2}$ eq (Lithuania's National Inventory Report, 2017), and it is expected to increase to $375 \mathrm{Mt} \mathrm{CO}_{2}$ eq by 2030 (European Commission, 2016). The Nationally Determined Contribution of the EU and its member states is targeted reduction of at least $40 \%$ in GHG emissions by 2030 compared to 1990 (Submission by ..., 2015). In addition to that, similarly to other EU member states, Poland is participating in Emission Trading System, has binding targets for $\mathrm{CO}_{2}$ in non-ETS sectors and is bound by EU LULUCF regulation.

As of 2016, the share of renewable energy used in final consumption in Poland was $11.3 \%$, in heating and cooling it was $14.7 \%$, in electricity $13.4 \%$ and in transport $3.9 \%$ (Eurostat).

The renewable energy targets for 2020 are yet to be achieved. For final energy consumption the target is $15.5 \%$, for heating and cooling $17 \%$, for electricity generation $19.3 \%$ and for transportation energy $10 \%$ (REN21, 2017). A new energy policy until 2050 with a main focus on 2030 is under preparation by the Polish government.

The Polish energy sector is largely based on fossil fuels - hard and brown coal. In 2016, the main sources for electricity generation were hard coal (50\%), brown coal (lignite) (31.4\%), and wind power (7.14\%). Among renewable energy sources, the capacity of wind farms installed in Poland amounted to $69 \%$ of all renewable energy capacity. Biomass came in second place (15.2\% share), followed by hydro (11.8\%) in 2016 (The Polish Wind Energy Association, 2017). Relatively significant development has taken place in the onshore wind sector during the last three years: the capacity has increased from 3,836 MW in 2014 to 4,886 MW in 2015 and 5,807 MW in 2016 (IRENA, 2017). 
Findings

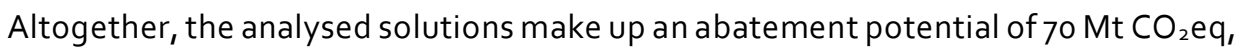
which forms $19 \%$ of Poland's net GHG emissions projected for 2030. The solutions with the highest abatement potential are the ones related to energy efficiency: energy efficiency in buildings would bring about $26 \mathrm{Mt} \mathrm{CO}_{2}$ eq of decrease and energy efficiency in industry about $16 \mathrm{Mt} \mathrm{CO}_{2}$ eq. Bioenergy for heating and solar power would both result in about $9 \mathrm{Mt} \mathrm{CO}_{2}$ eq of abatement. The rest of the solutions have abatement potential less than $4 \mathrm{Mt} \mathrm{CO}_{2}$ eq each.

Putting the individual solutions into the context of Poland's projected GHG emissions for 2030, the individual potential of various solutions comprises up to $7 \%$ of the projected net emissions level: $2 \%$ from solar power, $3 \%$ from bioenergy for heating, $4 \%$ from energy efficiency in industry and $7 \%$ for energy efficiency in buildings.

Figure 7: Abatement potential of different solutions by 2030, Poland $\left(\mathrm{Mt} \mathrm{CO}_{2} \mathrm{eq}\right.$ and $\%$ of 2030 emissions)*

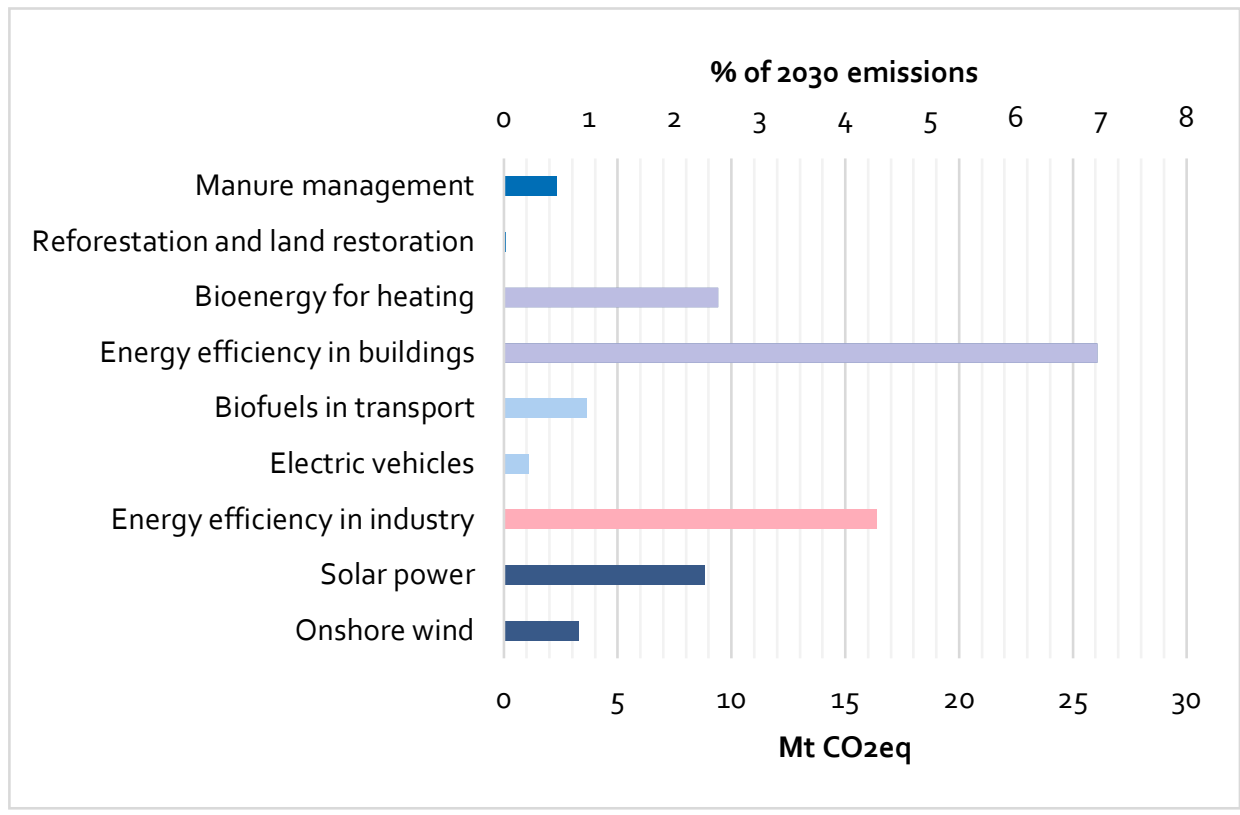

Note: * As Poland is above benchmark for CHP, this solution is not presented in the Figure. Also, reforestation and land restoration abatement potential is not visible in the Figure as it is very low in Poland (o.08 $\mathrm{MtCO}_{2}$ eq). 
Key recommendations for the solutions with highest potential

On energy efficiency in buildings and industries, a combination of financial incentives, such as investment grants, tax credits, leasing models, and capacity building can tap into the potential of these solutions. Instruments to promote better self-organisation of inhabitants can be useful for multi-apartment buildings, e.g. via mandatory apartment associations in order to form legal body for managing the negotiations, financial resources and construction works related to renovation. This has to be accompanied by a strong advisory system in order to reach out to apartment associations and homeowners with less know-how and skills.

Energy efficiency could deliver significant abatement as EU funds are available to Poland to support investments and to promote energy efficiency and reduce energy use. Removal of fossil energy subsidies would motivate further investments into renewable energy in heating and electricity generation.

\subsubsection{Ukraine}

\section{Country profile}

In 1990, GHG emissions in Ukraine were $910 \mathrm{Mt} \mathrm{CO}{ }_{2}$ eq (Ukraine's Greenhouse Gas Inventory, 2017) and decreased to $308.6 \mathrm{Mt} \mathrm{CO}_{2}$ eq by 2015 (Ukraine's Greenhouse Gas Inventory, 2017). For Ukraine, it is not possible to use the same source for baseline development as for other countries, as Ukraine is not a member of European Union (for previous countries, EU Reference Scenario was used). Instead, the baseline for Ukraine is based on projections done for EBRD (Factor $\mathrm{CO}_{2}, 2011$ ). In this report, four different scenarios are presented: two for the baseline (worst-case scenario and base case scenario) and two mitigation scenarios. The projections of base case scenario are used in the current report. By 2030 the base case scenario projects the GHG emission level to be $694 \mathrm{Mt} \mathrm{CO}$ eq (Factor $\mathrm{CO}_{2}, 2011$ ). Contrary to the other four countries, in which a reduction or small increase of GHG is foreseen by 2030, a very significant increase is foreseen for Ukraine. This is resulting from the fact that other four countries are members of the EU and have already taken several measures to decrease GHG emissions, while in Ukraine these measures have not yet been implemented. In addition, the development level of Ukraine is the lowest among the countries in the study, which has implications as well.

Ukraine's Nationally Determined Contribution is ambitious: GHG emissions will not exceed $60 \%$ of 1990 level by 2030 (INDC of Ukraine, 2015). Translated to absolute values, Ukrainian GHG emissions should not exceed $546 \mathrm{Mt} \mathrm{CO}_{2}$ eq by 2030.

The share of renewable energy used in final consumption in Ukraine was $3.5 \%$ as of 2014 (World Bank, 2018). Renewable energy sources accounted for around $6.4 \%$ of the total electricity generation by January 2017 (Antonenko et al. 2018).

Ukraine has committed to a $11 \%$ renewable energy target for gross final energy consumption by 2020 . The national renewable energy targets are: for electricity generation $11 \%$ by 2020 and $20 \%$ by 2030 ; for heating and cooling $12.4 \%$ by 2020 ; and for transportation energy $10 \%$ by 2020 (REN21, 2017). According to the Energy Strategy of Ukraine for the period up to 2035, adopted in 2017, the target for 2035 is $25 \%$ of electricity generation from renewable sources. 
At present, Ukraine is still heavily dependent on coal, natural gas and nuclear energy. The latter is the main source for electricity generation. Wind power makes up $51.5 \%$ of the annual renewable electricity production, followed by photovoltaic (27.8\%) and small hydro power plants (10.6\%) (UWEA, 2017). Although Ukraine has started to reform its energy sector, a lot remains to be done. Ukraine has voluntarily agreed to adopt the European Union's internal energy market legislation and its power sector must meet EU environmental standards as a requirement under the EU Association Agreement.

\section{Findings}

The abatement potential of different solutions altogether in Ukraine is $62 \mathrm{Mt} \mathrm{CO}_{2}$ eq (Figure 8). In absolute terms, it is quite similar to Poland, but it makes up a much smaller share of Ukraine's projected 2030 net emissions ( $9 \%$ in total for solutions), as compared to Poland due to the fact that GHG baseline emissions of Ukraine are projected to increase considerably. The solution with the highest abatement potential is energy efficiency in buildings (about $25 \mathrm{Mt} \mathrm{CO}_{2}$ eq), followed by onshore wind ( $12 \mathrm{Mt} \mathrm{CO}_{2}$ eq). The other solutions have an abatement potential of about $7 \mathrm{Mt} \mathrm{CO}_{2}$ eq or less.

Comparing the abatement potential of different sectors, the highest potential is from energy sector solutions (22 $\mathrm{Mt} \mathrm{CO}_{2}$ eq) and solutions for buildings and households (29 $\mathrm{Mt} \mathrm{CO}_{2}$ eq).

Putting the abatement potential of solutions into the context of 2030 net GHG emissions of Ukraine, which are projected to be $694 \mathrm{Mt} \mathrm{CO}_{2}$ eq, the highest potential is offered by energy efficiency in buildings $(4 \%)$ and onshore wind $(2 \%)$. The rest of the solutions offer abatement potential which is less than $1 \%$ of the net GHG emission level.

Figure 8: Abatement potential of different solutions by 2030, Ukraine ( $\mathrm{Mt} \mathrm{CO}_{2} \mathrm{eq}$ and $\%$ of 2030 emissions)*

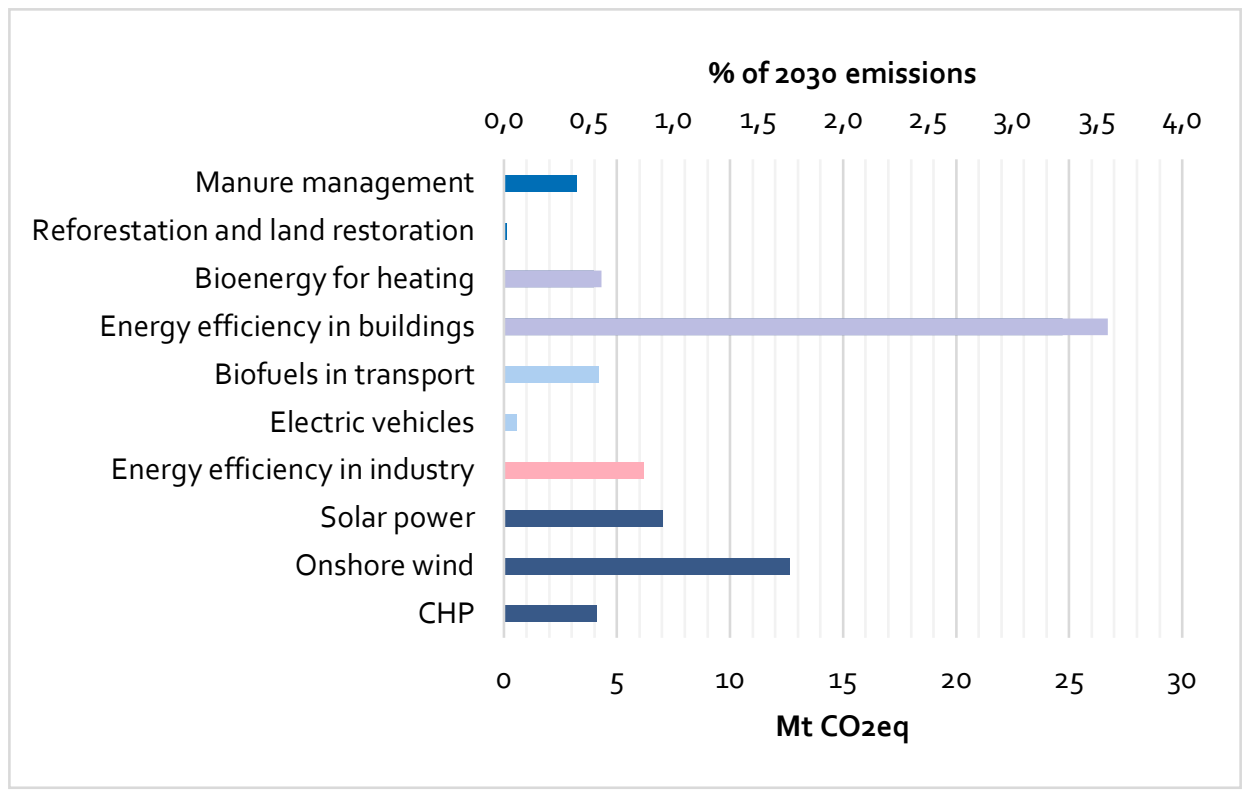

Note: * Reforestation and land restoration has been assessed for Ukraine, but the abatement potential is very modest ( $0.09 \mathrm{Mt} \mathrm{CO}_{2}$ eq) and thus does not appear in the Figure. 


\section{Key recommendations for the solutions with highest potential}

On energy efficiency in buildings, a combination of financial incentives, such as investment grants, tax credits, leasing models, and capacity building can tap into the potential. This means that more investment funds for efficiency improvements would be needed in Ukraine. Continuing the anticorruption and transparency initiatives that Ukraine has started in the energy sector would also result in economic gains which can be invested in energy efficiency.

For realising the potential of onshore wind, agreement on the long-term goals and measures for renewable energy would help ensure a stable legal and investment framework. Removal of fossil energy subsidies and creating clear $\mathrm{CO}_{2}$ pricing mechanisms would motivate further investments into renewable energy.

It might be useful to consider a bidding system for onshore wind projects and to make sure that there are no administrative or technical barriers for wind power development. Investments into grid reinforcement and modernisation and supporting connection to network are also needed. Open dialogue with affected community members is recommended from the outset of wind park siting to minimize the environmental impacts of wind power generation and to plan local community benefits. 


\section{Methodological approach}

\subsection{Methodology for quantitative analysis}

The quantitative analysis is largely based on the methodology developed by Ecofys for the original global Green to Scale report (Ecofys, 2015). The application of the methodology was further developed by CICERO in the Nordic Green to Scale report (Korsbakken \& Aamaas, 2016).

Calculation of the associated net emission reductions in the target countries consisted of the following main steps:

1. Defining the degree of implementation in the originating country (also called benchmark or scale-up level in the report). Depending on the solution, the share of technical potential by 2030 or growth rate in our target countries has been used. The assumption is that the share of technical potential related to an abatement solution realized by the benchmark country (e.g., potential of onshore wind realized in Denmark) to date can be achieved by the target countries by 2030 . Where applicable, the growth rate of implementation was used instead;

2. Finding a baseline level of 2030. Baseline level refers to the expected level which would be achieved in these countries with currently applied and planned policies and not including additional policy measures. Hence, baselines do not equate with national targets from various strategy documents, but current actual trajectories the countries are on. For most of the solutions, baselines for the four EU member countries are from EU Reference Scenario (European Commission, 2016). For Ukraine, different available sources have been used;

3. Additional abatement potential was calculated by finding the difference between baseline and scale-up levels by 2030. For example, in case of onshore wind, the amount of emissions would be equal to the avoided emissions of conventional energy due to higher penetration of wind energy; or in case of electric vehicles it would be the emissions associated with higher energy efficiency of electric vehicles and avoided conventional fuel consumption;

4. If necessary, the abatement potential was adjusted downwards in countries where interpolation results cross plausible limits (e.g. market share), defined by the project team; 
5. The total cost of each solution was calculated according to unit abatement cost (per tonne $\mathrm{CO}_{2}$ eq) and multiplying the unit abatement cost by the total net abatement potential. For most of the solutions, we have used the McKinsey cost curve (McKinsey \& Company, 2009), similarly to Nordic Green to Scale, but adjusted the values to the 2017 values. For solutions where the role of labour is larger, purchasing power parity (PPP) adjustments were made in case of all countries.

\subsection{Methodology for qualitative analysis}

In the qualitative analysis, the main country-level enabling factors, barriers and cobenefits for each solution were identified based on literature and expert knowledge, and further discussed with local experts. In this study, enablers are defined as conditions and measures that facilitate the scaling up of the selected solutions by increasing their competitiveness and are essential to their success. Barriers are limiting factors, mostly on a political or societal level, to the wider deployment of chosen technologies and practices. Co-benefits are additional environmental, economic and social gains stemming from the implementation of the solution and reduction of GHG emissions. As the main reference sources for the enabling and limiting factors, experiences of the benchmark and target countries were used.

Policy recommendations were derived from the key findings of the country-specific quantitative and qualitative analysis of the solutions. The draft recommendations were discussed with local experts in the focus groups and phone interviews. The aim of the policy recommendations is to help the countries to improve the uptake and deployment of the selected ten solutions.

For validating the quantitative and qualitative desk research results and gathering country-specific input three focus groups were organised in Riga (Latvia), Vilnius (Lithuania) and Kiev (Ukraine) in December 2017. In Estonia, expert assessments were used for the analysis. For the Polish results, phone interviews were conducted in January 2018. The interviewees and focus group participants are listed in Annex. 


\section{Energy sector solutions}

\subsection{CHP and district heating}

\subsubsection{Description of the solution}

Combined heat and power production/cogeneration (CHP) is generating heat and electricity at the same time. While in the conventional power plant the heat generated alongside the power generation is in many cases to be wasted because of the lack of relevant heat load, in CHP plants the heat is recovered to be used for heating households or industry. The frontrunners for CHP are Denmark and Finland. In Denmark, $60 \%$ of households are connected to district heating system and about $70 \%$ of heat delivered through this system originates from CHP plants (Danish Energy Agency, 2018). In Finland, about three-quarters of district heat and one third of electricity is delivered from CHP plants (Finnish Energy, 2018). In addition, Finland produces a majority of heat for industrial use also from CHP (Statistics Finland, 2017).

The solution hence is providing heat from CHP plants for heating of households through district heating and to industry from nearby power plants or on-site generating units. The degree of implementation is the percentage of total heat delivered by CHP in this manner. Due to the very different nature of the mentioned two sectors (district heating for households and industrial heat), these are treated separately in calculations. This is similar to the method applied in the Nordic Green to Scale study (Korsbakken \& Aamaas, 2016). Similarly, we have left out district cooling which is more relevant in southern countries. As our studied countries have a relatively cold climate, this is not currently relevant, but could become more relevant in future.

\subsubsection{Scale-up method and baseline}

The Finnish level (in 2013) has been used as benchmark for both industrial (food, wood, paper and chemicals) and urban district heating. Although the share of heat delivered from CHP plants is on quite similar level in Denmark, Finland distinguishes by also providing a majority of heat for industrial use from CHP plants and hence Finland has been used as benchmark for this solution.

The baseline for annual heat consumption growth in urban areas was based on the EU reference scenario, varying depending on a country between $0.34 \%$ and $1.74 \%$, (European Commission, 2016). For Ukraine, $-0.5 \%$ growth was assumed, based on the historic trend. The baseline for heat consumption growth in industries was based on the historic trend for 2006-2015 (Eurostat).

The urban average of $\mathrm{CO}_{2}$ intensity of final heating energy, which varies between 23 (Lithuania) to 94 (Poland) $\mathrm{tCO}_{2} \mathrm{eq} / \mathrm{TJ}$, was also used for industries. 
The abatement potential was not estimated for Poland and Latvia (neither for industries nor urban district heating), and for Ukraine industries as current (2015) share of CHP heat exceeds the benchmark level.

Neither industry nor urban specific information about the CHP share in heating was available for the Baltic countries or Poland. Hence, the overall average share was used.

\subsubsection{Net abatement potential}

The net abatement potential of CHP and district heating is given in the following table.

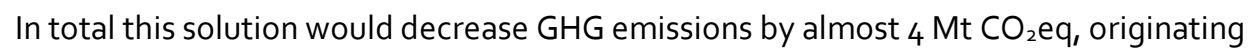
from Estonia, Lithuania and Ukraine. By far, the highest potential is in Ukraine, where $\mathrm{CHP}$ and district heating would mean a decrease of $3.77 \mathrm{Mt} \mathrm{CO}_{2} \mathrm{eq}(0.5 \%$ of country emissions in 2030). The role of Estonia and Lithuania in this total is modest: 0.06 and $0.07 \mathrm{Mt} \mathrm{CO}_{2}$ eq, which would mean $0.4 \%$ of GHG emissions in these countries in 2030 . This solution is not estimated for Latvia and Poland, as their current share already exceeds the benchmark level.

Table 2: The target countries' abatement potential in 2030 ( $\mathrm{Mt} \mathrm{CO}_{2} \mathrm{eq}$ and \% in 2030 emissions)

\begin{tabular}{lrr} 
Country & Mt CO ${ }_{2}$ eq & $\begin{array}{r}\text { \% of 2030 emissions of } \\
\text { respective country }\end{array}$ \\
Estonia & 0.06 & 0.4 \\
Latvia & $\mathrm{NA}$ & $\mathrm{NA}$ \\
Lithuania & 0.07 & 0.4 \\
Poland & $\mathrm{NA}$ & $\mathrm{NA}$ \\
Ukraine & 3.77 & 0.5 \\
Total & 3.91 & 0.5 \\
\hline
\end{tabular}

\subsubsection{Abatement costs}

Total abatement costs are presented in the following table. Unit abatement cost is based on Nordic Green to Scale methodology, which in turn uses the McKinsey cost curve, adjusted to latest value. The marginal abatement cost is negative $\left(-5,3 \mathrm{EUR} / \mathrm{tCO} \mathrm{C}_{2} \mathrm{eq}\right)$ for industries and new buildings ( $\left.-188 \mathrm{EUR} / \mathrm{tCO} \mathrm{C}_{2} \mathrm{eq}\right)$, but positive for existing buildings (216 $\mathrm{EUR} / \mathrm{tCO}_{2} \mathrm{eq}$ ).

Table 3: Abatement cost for CHP in 2030 (in 2017 EUR)

Cost

Unit abatement cost $\left(\mathrm{EUR} / \mathrm{tCO}_{2}\right)$ - urban district heating, including: 


\subsubsection{Important enablers}

Additional CHP plants can be planned in the district heating systems where the heat consumption is relatively high all the year round and where a CHP plant has not been set up yet. In Estonia, there is potential for cogeneration plants in smaller towns (EREA, 2017). In Lithuania, the largest share of district heating is produced by biomass boilers. However, there are plans to build waste-burning CHP plants in Vilnius and Kaunas which are the largest district heating markets. After their construction, there will be much less potential for new CHP plants there. Ukraine has invested a significant amount in biomass fuelled heat-only boilers. There is also potential for CHP development in Poland, although the country is already above the benchmark.

Since the capital expenditures for CHP and district heating are high, financial incentives to establish or maintain the necessary infrastructure and equipment may be necessary for the large-scale deployment of the solution. The Baltic states and Poland have investment support programmes for district heating systems available under the EU Funds programmes $2014-2020$ as well as national feed-in tariffs for efficient combined heat-power production. There are also specific financial support programmes available in Ukraine, e.g. from the World Bank to Ukrainian district heating companies (2014-2020).

The efficiency of CHP is higher if energy intensive industrial plants, residential areas and public utility CHP plants are located close to each other, i.e. the consumption density all the year round is relatively high. Therefore cooperation with heat providers and local governments is needed to maximise deployment of CHP and district heating with new buildings (real estate development areas, enterprises, etc.) and to minimize the need for retrofitting (Korsbakken \& Aamaas, 2016).

Environmental protection and energy efficiency targets as required by the EU Energy Efficiency Directive also facilitate the construction of CHP plants in district heating systems in order to reduce the air emissions.

In Finland, the benchmark country, CHP has been very successfully incorporated into both district heating and industry - the key roles have had the country's cold climate giving a good return on heat supply infrastructure investment and its widely developed forestry and paper industries with their associated high heat demand. Therefore the overall high national level of CHP utilisation has been market driven with little direct government support (OECD/IEA, 2013).

\subsubsection{Possible barriers}

Since building CHP and district heating grid is capital intensive with long payback time, especially in the case of residential heating, it can create a significant financial barrier for municipalities and industries without subsidies. Previously made large investments into biomass fuelled heat-only boilers, as in Ukraine, can limit new investments into more efficient CHP plants. Similarly, the lack of sufficient complementary subsidies for CHP to match renewable energy investment incentives that reduce the price of electricity can discourage investing in CHP plants. 
Furthermore, the lack of heat demand, as a result of improved thermal insulation of buildings and declining populations in small towns and rural areas, hinders the wider deployment of CHP plants due to their economic inefficiency. Although more people move to cities, the heat demand is not expected to considerably increase there either as the energy efficiency of houses is improving. The relatively high share of buildings which are heated by individual heating solutions (boilers or stoves) also limits the opportunities of CHPs by locking some of the potential demand into off-grid solutions (e.g. in Ukraine, Poland, Estonia) (Euroheat \& Power, 2017).

Thus CHP and district heating are subject to competition from all measures aimed at reducing heating energy demand in buildings. Improved building energy efficiency has a similar or better economic value, combined with fewer actors to coordinate and a less complex infrastructure (Korsbakken \& Aamaas, 2016).

\subsubsection{Major co-benefits}

CHP increases fuel efficiency compared to the production of the same amount of thermal energy and electricity separately. Heat surpluses that would otherwise be lost can be recovered in the district heating system or technological processes. Dispersed electricity production reduces grid transaction losses and CHP units can increase security of supply. District heating networks also allow for more flexible changes in fuels used compared to boilers/heating installations installed locally. Thus, CHP plants help reduce import dependence and increase energy security.

With lower total energy use, CHP and district heating reduce air emissions of sulphur compounds and thus create health benefits compared to a situation where the energy is derived from oil. Construction of CHP plants creates jobs for engineers and technicians, and in the case of biomass fuelled CHP plants, CHP also economically benefits forest owners and forest industries who provide the wood chips with biomass residues.

\subsubsection{Policy recommendations}

Given the above mentioned drivers of success in the benchmark countries and the key enablers and barriers, the following policy recommendations are made:

- Prioritising policies for the introduction of CHP in the case of significant heat loads. This includes ensuring the competitiveness of electricity produced through CHP in the market as the cost of an additional investment in electricity generation per unit of electricity is higher than the cost of an investment per unit of heat output. Feed-in tariff for CHP based electricity is an option for that;

- Ensuring opportunities of competition for new CHP capacities in existing district heating networks. For example, Estonia has put into place a mandatory competitive process based on energy efficiency for new CHP capacities; 
- De-monopolisation and unbundling of the district heating companies into independent heat production and heat transmission-distribution can be recommended for developing competitiveness of the heat production market of Ukraine. At present, the state government regulates the energy prices that limit the entrance of new energy providers. This would also provide incentives for reducing heat losses and ensure transparent competition among heat producers;

- Continuing or providing financial incentives for promoting energy efficient CHP generation, e.g. investment support for the establishment and refurbishment of district heating systems and small-scale and biomass/biogas fuelled CHP plants;

- Cooperation between heat providers and local governments in urban planning to maximise deployment of CHP and district heating with new real estate development areas and industrial enterprises.

\subsection{Onshore wind power}

\subsubsection{Description of the solution}

Similarly to the Nordic Green to Scale study, we use the average of Denmark and Sweden share of built-up wind power potential as the benchmark. Denmark is known for its high development in wind power, as it has installed wind turbines already starting from 1970 and for having an ambitious goal of a fossil free energy system by 2050 (Danish Energy Agency, 2018). Sweden is also among the few European countries where more than $6 \mathrm{GW}$ of wind power have been installed (WindEurope, 2017a), most of which is onshore. Denmark has installed about $5 \mathrm{GW}$ of wind power, with about a quarter offshore (WindEurope, 2017a). The countries are very different from the perspective of density and penetration of onshore wind and can be treated as two outliers: Sweden as a large country with low population density and Denmark as a small country with high population density. To provide adequate potential, but also to retain comparability to previous Green to Scale report, the average share of built-up potential in Denmark and Sweden in terms of wind power production is used in this report also. Hence, the scale-up potential is calculated based on onshore wind power production (TWh).

While onshore wind production figures of 2014 (11 TWh in Sweden and 9.3 in Denmark) were used for the Nordic Green to Scale study (Korsbakken \& Aamaas, 2016), the Swedish figures had increased considerably by 2015 (15.6 TWh). In Denmark production remained at 9.3 TWh (IRENA, 2017). Based on these production figures, we calculated the average share in relation to technical potential of onshore wind. The scale-up method and potential is described in the following section.

In general, onshore wind energy production has increased considerably in the Baltics, Poland and Ukraine since 2005 (see next table). This is due to the implementation of different policy measures, as feed-in tariffs/premiums have been 
used in Estonia, Latvia, Lithuania and Poland for years already. In addition, the cost of the technology has decreased. The production potential is still much higher, realising this potential depends on different enablers and barriers which will be discussed below.

Table 4: Wind power generation in 2005 and 2015 in the target countries (GWh)

$\begin{array}{lrr}\text { Country } & 2005 & 2015 \\ \text { Estonia } & 54 & 715 \\ \text { Latvia } & 47 & 147 \\ \text { Lithuania } & 2 & 810 \\ \text { Poland } & 135 & 10,858 \\ \text { Ukraine } & 38 & 1,084\end{array}$

Source: IEA database 2017.

\subsubsection{Scale-up method and baseline}

As already discussed above, the scale-up level in this case is the average built-up share of technical onshore wind potential of Sweden and Denmark. While this share was $6.8 \%$ in Nordic Green to Scale study based on 2014 data, by 2015 this share has increased to $7.3 \%$. This $7.3 \%$ is used as scale-up level in this report, as a share of actual production in relation to technical potential of onshore wind that could be reached by our target countries by 2030. The issue of technical potential is of importance here. There is no standard source for assessing the technical potential of onshore wind for all five target countries. The technical potential of Sweden has been assessed to be $510 \mathrm{TWh}$ (Greenpeace, EREC, 2011). For other countries, unrestricted technical potential has been assessed by the European Environment Agency (2009), for Sweden this has been assessed to be 5,050 TWh. The unrestricted technical potential is kind of "raw potential of onshore wind", which does not take into account different land-use restrictions (e.g. related to biodiversity) nor cost issue (not all potential is economically competitive). We have used the ratio for Sweden based on these two previously mentioned potentials (10\%) also for other countries (Baltic countries and Poland) as estimation for reasonable technical potential of onshore wind production.

There is no data for Ukraine in the EEA report. IRENA (2015b) has estimated the potential of onshore wind energy capacity in Ukraine to be in the range of 16-24 GW. No estimation about production potential (TWh) has been given in this IRENA report. Hence, we base the assessment of potential electricity production potential on the ratio of potential in unrestricted technical potential as discussed in previous paragraph in case of Sweden. 
Table 5: Unrestricted and restricted production potential of onshore wind

\begin{tabular}{|c|c|c|}
\hline Country & $\begin{array}{r}\text { Unrestricted technical potential of } \\
\text { onshore wind based on EEA } \\
(2009) \text { report (TWh) }\end{array}$ & $\begin{array}{r}\text { Restricted potential used in this } \\
\text { study based on ratio of } \\
\text { Sweden (TWh) }\end{array}$ \\
\hline Sweden & 5,050 & 510 \\
\hline Estonia & 672 & 67 \\
\hline Latvia & 853 & 85 \\
\hline Lithuania & 746 & 75 \\
\hline Poland & 3,682 & 370 \\
\hline Ukraine & $\ldots$ & 370 \\
\hline
\end{tabular}

Based on the IRENA reports (2015a and 2015b), the technical potential of onshore wind energy in terms of capacity is in quite similar range for Poland and Ukraine. Hence, we assume that Ukraine's onshore wind production potential is at least that of Poland's and we have applied the potential onshore wind power production by 2030 in Poland also to Ukraine. However, it might slightly underestimate the actual Ukrainian potential.

For the baseline for onshore wind by 2030 we use the EU reference scenario (European Commission, 2016), while in Ukraine, data from IRENA (2015b) is used - more specifically the Reference Case, which provides development with current policies in place.

We apply the restriction that wind power does not occupy more than $40 \%$ of a country's electricity mix. It should be noted, however, that Denmark has actually passed this level when onshore and offshore wind energy are combined. However, here the solution only applies to onshore wind.

The electricity production projection data are also from the EU reference scenario in the cases of Estonia, Latvia, Lithuania and Poland. For Ukraine, electricity production projection is from the Ukrainian Energy Strategy 4 .

The $40 \%$ restriction causes reduced shares in Estonia and Latvia (see next table). This means that based on the scale-up level (the average share of Sweden and Denmark), wind power generation could be 4.9 and 6.3 TWh in Estonia and Latvia respectively. However, if $40 \%$ of projected electricity production in these countries is calculated for 2030, this would result in 3.77 and 3 TWh of potential wind power production in Estonia and Latvia. The $40 \%$ market share limitation does not cause restrictions in other countries.

\footnotetext{
4 New Energy Strategy of Ukraine till 2035: Security, Energy Efficiency, Competitiveness. Kyiv 2017 ; https://www.kmu.gov.va/en/news/250210653

Short summary can be accessed here

http://razumkov.org.ua/uploads/article/2017_NES\%202035_RazumkovCentre_Ukraine_September\%202017_description.pdf
} 
Table 6: Scaled up level of wind energy production and 40\% market share limitation by 2030 (TWh)

$\begin{array}{lrr}\text { Country } & \text { Scaled-up level of production } & \text { 40\% market share limitation } \\ \text { Estonia } & 4.94 & 3.77 \\ \text { Latvia } & 6.26 & 3.00 \\ \text { Lithuania } & 5.48 & 5.76 \\ \text { Poland } & 27.04 & 81.20 \\ \text { Ukraine } & 27.04 & 74.00\end{array}$

As a result the $40 \%$ market share limitation may be too conservative considering the changes in the electricity market, more specifically the integration of the Nordic-Baltic electricity market. Thus, this might not be an adequate constraint in the future. However, for the lack of a better benchmark available currently, we have left this constraint in our calculations. When the markets integrate, the wind market may form a larger share of the market and the abatement potential would be higher than calculated in this study.

\subsubsection{Net abatement potential}

The estimated amount of onshore wind production above the baseline is $30 \mathrm{TWh}$ in 2030 for the five target countries. The majority of this originates in Ukraine (about 19 TWh). As EU member states, the rest of the countries have already implemented several policies to advance wind production and the baseline for these countries is quite high. Thus, the potential for the Baltic countries and Poland is significantly lower.

As projections for $\mathrm{CO}_{2}$ intensity of electricity on the country level for 2030 are lacking, we have used the $\mathrm{CO}_{2}$ intensity of electricity at the regional level (Eastern Europe) by 2030 (0.607 $\mathrm{Mt} \mathrm{CO}_{2} / \mathrm{TWh}$ ) (IEA, 2015).

Ukraine has the highest abatement potential for onshore wind, as is seen in Table 6 below, due to a reduction of about $12 \mathrm{Mt} \mathrm{CO}_{2}$ eq (about $2 \%$ of national emissions in 2030). For other countries, the abatement potential in absolute numbers is lower, ranging from $1.43 \mathrm{Mt} \mathrm{CO}_{2}$ eq for Latvia up to $3.27 \mathrm{Mt} \mathrm{CO}_{2}$ eq for Poland (Table 6). The share of onshore wind abatement potential in country emissions is the highest in the Baltics: $12 \%$ in Estonia, $14 \%$ in Latvia and more than $16 \%$ in Lithuania. For Poland, this share is modest: $0.9 \%$ of projected $2030 \mathrm{GHG}$ emissions. 
Table 7: The target countries' abatement potential in 2030 ( $\mathrm{Mt} \mathrm{CO}_{2} \mathrm{eq}$ and \% in 2030 emissions)

\begin{tabular}{lrr} 
Country & Mt CO 2 eq & $\begin{array}{r}\text { \% of 2030 emissions of } \\
\text { respective country }\end{array}$ \\
Estonia & 1.67 & 12.2 \\
Latvia & 1.43 & 14.2 \\
Lithuania & 2.83 & 16.5 \\
Poland & 3.27 & 0.9 \\
Ukraine & 11.69 & 1.7 \\
Total & 20.89 & \\
\hline
\end{tabular}

\subsubsection{Abatement costs}

To calculate the abatement costs, we have used the same unit cost for onshore wind as in the Nordic Green to Scale study, which in turn is based on the McKinsey cost curve adjusted for 2017 values. Hence, the unit cost of onshore wind would be $24 \mathrm{EUR} / \mathrm{tCO}_{2}$ by 2030 . As the costs are mostly related to technology, we have used the same unit cost for all of the target countries. However, there are uncertainties related to future costs of onshore wind solutions. The costs are expected to decrease, but the extent of change depends on various factors. According to onshore wind experts, the key factors are technology development (rotor diameter and design, tower height, durability, etc.), but also financing costs and market development (Wiser et al. 2016). As the cost development is uncertain and driven by different factors, and also for keeping consistency with previous Green to Scale reports, we rely on the unit cost based on the McKinsey cost curve. The unit cost used there is the weighted average of low penetration and high penetration case of wind, whereas the high penetration case includes integration costs for additional load following, regulation reserves and grid extension costs. This would mean that the total abatement costs for onshore wind would be EUR 492 million in 2030 (Table 7).

Table 8: Abatement cost for onshore wind in 2030 (in 2017 EUR)

\subsubsection{Important enablers}

Large-scale onshore wind power development requires certain climate and geographic conditions: suitable wind resources and sufficient land area. Sites close to the shoreline usually have better wind conditions (the Baltic Sea, the Black Sea and the Azov Sea in the target countries). While all the Baltic Sea region countries have significant wind potential, it has been assessed that Estonia has better wind resource than Lithuania and Latvia (BENTE, 2018). Also, Ukraine possesses excellent wind resource to support the development of large wind projects (UWEA, 2017). 
Important enablers for scaling up this solution are reductions in the prices of wind technology and support schemes, such as feed-in premiums, feed-in tariffs, tradable green certificates and tenders. In Denmark, the benchmark country, wind turbines have largely been built by using feed-in tariffs, while Sweden has a history of green certificates (Korsbakken \& Aamaas, 2016). Significant cost reductions for wind energy in Europe have been achieved with the increased use of competitive bidding processes (e.g. tenders) by states to select wind energy projects (WindEurope, 2017b). State policies which prioritize renewable energy can lead to the situation where building of wind farms does not require any support outside of a state supported grid connection. An auction-based system for renewable energy projects is used e.g. in Poland and Lithuania (Nagevičius, 2017). Estonia, Latvia and Ukraine are considering introducing bidding mechanism for wind energy based on the desired amounts of kWh.

Technological development towards sufficient energy storage (e.g. large scale battery storage, pumped hydro, transformation of wind based electricity to hydrogen, underground compressed air, etc.) would enable the coverage of fluctuations in energy generated by wind power. Local pumped hydro is available e.g. in Lithuania. Availability of adequate reserve capacity of other electricity sources, which are automatically managed by the demand side (use of electricity at times of high supply), also contribute to the smooth operation of the power system.

Wind power can be best combined with other dispatchable power sources in a large coordinated electricity market, which has helped Denmark to achieve its current record share of wind power in its electricity mix (Korsbakken \& Aamaas, 2016). The Nordic electricity market has plentiful reserves of hydropower and other dispatchable sources in Norway and Sweden for times when wind generation in Denmark is low. It also enables to sell surplus electricity in the relatively frequent instances when Denmark's wind power generation exceeds domestic demand.

From 2018 onwards, electricity balancing in Estonia, Latvia and Lithuania is carried out at the level of the three Baltic countries. The creation of the common electricity balancing market is one of the main steps towards the integration of the Baltic electricity markets. Also, starting from 2019, Ukraine will have the same rules as EU for the functioning of the electricity market.

In most cases, the transmission grids need to be expanded for large-scale wind power deployment. Policies that give preferential access to the grid for renewable energy compared to fossil based electricity can be useful to help overcome transmission capacity limitations to a certain point. For example, in Lithuania up to $500 \mathrm{MW}$ of additional wind can be integrated in the grid without significant costs (Radavičius, 2017). Priority use of the grid for renewable energy has helped create a positive investment climate in Denmark (Danish Energy Agency, 2018).

As public acceptance of wind turbines and support schemes is also one of the most important enablers, measures for greater citizen involvement into planning and the generation of local economic benefits play an increasing role in the development of wind power. Denmark has from the outset promoted the ownership of wind power by local citizens, companies and cooperatives through planning schemes and specific regulations. Commercialisation of wind power in Denmark has shown that when actors 
external to local communities started implementing wind projects, local resistance against wind projects emerged as local citizens felt excluded from decision-making and economic benefits (Bauwens et al. 2016).

\subsubsection{Possible barriers}

For further wide-scale onshore wind power development, limited space availability and land use restrictions will become a considerable obstacle due to large amount of land required for wind turbines. Potential areas for new installations may have already been designated as protected areas, military radar areas, etc. Limiting factors are connected with the protection of birds and bats, with the generation of sound, visual impacts or other distance- and location-related aspects.

For property owners, restrictions on the use of property due to the need to keep statutory distance between wind turbines and buildings may create a barrier to accept an installation. Although early stakeholder-based approaches to the wind park development take more time and resources, they are of critical importance for determining the project outcome.

As wind farm development is expensive, political uncertainty about carbon pricing policy, legal framework and support mechanisms, as well as access to the grid can pose additional constraints for investors. Also, technological solutions are not yet sufficiently advanced to store the excess generation of wind power from windy periods and to distribute it during times of high demand. Insufficient storage capacity is keeping conventional power plants in operation to back up renewable energy sources.

\subsubsection{Major co-benefits}

The major co-benefits of wind power development are related with improved air quality and energy security. Wind power generation help reduce local air pollutants $\mathrm{SO}_{2,} \mathrm{NO}_{x}$ and $\mathrm{PM}_{2.51}$ which bring along public health benefits. There are no emissions during the operation of wind turbines. Related environmental benefits include reduced water use and no waste generation compared to fossil fuel or nuclear power plants. The increased energy security is result of replacing imported fossil fuel-based electricity generation with domestic sources.

On average, more jobs are created for each unit of electricity generated from renewable sources than from fossil fuels (UCS, 2017). Wind power growth will generate new jobs directly in manufacturing, operations and management, as well as indirectly in upstream supply chains for materials and inputs for manufacturing. Local employment opportunities will also be generated during the construction and operating phases of wind farms. According to the Ukrainian Wind Power Association, about 500 wind power related jobs were created in Ukraine by the end of 2016, including 269 professionals working directly for wind companies (UWEA, 2017).

In general, wind parks have low operating and maintenance costs. For the owners of the land upon which the farms are installed, they result in financial benefits, such as land and/or property rents, which in turn produce tax revenues. However, for wind power developers these mean cost. 


\subsubsection{Policy recommendations}

Given the above mentioned drivers of success in the benchmark countries and the key enablers and barriers, the following policy recommendations are made:

- Agreeing on clear action plans with effective measures to achieve ambitious wind power targets by 2030 ;

- Keeping legal frameworks and support instruments stable over longer periods of time to ensure a transparent investment framework;

- Reviewing the administrative procedures and standards for wind power development (duration of permitting procedure, minimum distances from radars and other spatial planning zones);

- Making sure that transmission system operators (TSOs) remove technical barriers for further wind energy development and invest into grid reinforcement and modernisation;

- Open dialogue with affected community members from the outset of siting the wind park to minimize the environmental impacts of wind power generation and to plan local community benefits from onshore wind energy development;

- Commit to further integrating into regional electricity markets;

- Agreeing on carbon pricing policy (in Ukraine) and improving carbon pricing policy (in the EU) to avoid distortion of competition in favour of fossil energy producers;

- Implementing a tender-based/competitive bidding system for onshore wind energy projects in countries where it is not yet established (Estonia, Latvia, Ukraine).

\subsection{Solar power}

\subsubsection{Description of the solution}

For the benchmark of photovoltaic solar (PV) power, two countries (Germany and Denmark) were considered. Germany was selected as the benchmark country due to its higher share of solar power in electricity: 6\% in Germany vs. $2 \%$ in Denmark (IEA, 2017). In 2016, 1.5 GW new solar capacities were installed in Germany (Fraunhofer ISE, 2017). However, this is still not the capacity foreseen by different strategies. For example, the German Renewable Energy Act foresees an annual target of 2.5 GW of new solar power. If the country wants to satisfy the energy demand with renewable energy sources by 2050, about 4-5 GW of solar power should be installed annually (Fraunhofer ISE, 2017). The German feed-in tariff has been in place since 2000, but has recently undergone a substantial decrease. Additionally, there are limitations to new installations which have actually led to a decrease of new solar power installations (Fraunhofer ISE, 2017). However, based on the high percentage of electricity produced from solar, Germany is used as the benchmark for the scale-up potential of this solution. In 2015, Germany produced $38,726 \mathrm{GWh}$ of solar power, corresponding to $6 \%$ of electricity production 
(IEA 2017). By 2016, Germany produced already $7.2 \%$ of electricity from solar power (Fraunhofer ISE, 2018). This 2016 share is used for scaling-up. The scale-up method and potential is described in the following section.

In our target countries, solar power production has been modest: in Estonia and Latvia less than 1 GWh in 2015, in Lithuania 73 GWh, in Poland 57 GWh and in Ukraine 477 GWh (IEA, 2017).

\subsubsection{Scale-up method and baseline}

The scale-up method used in the Ecofys report (2015) is based on solar potential, which in turn is based on an assessment of the available amount of land, rooftops and facades, resource quality and technology. As robust data about these elements is unavailable for the target countries, the scale-up potential in this report is based on the solar share in electricity. We expect the five countries to produce $7.2 \%$ of their electricity from solar by 2030. The baseline numbers for the Baltic countries and Poland are from the EU Reference Scenario (European Commission, 2016). For Ukraine, the data is based on IRENA (2015), more specifically the Reference Case, which provides development scenarios based on implementation of current policies.

The scaling-up results in much larger capacities and production that can be seen in these countries at present. For example, in the Baltic countries, the potential solar PV production is in a range of 0.5-0.9 TWh, while for Poland 12 TWh and for Ukraine 11 TWh. The figures for Poland and Ukraine are also higher than the estimated solar PV potential by IRENA by 2030, which has estimated the solar potential for Poland to be 5 TWh by 2030 and for Ukraine to be 8.4 TWh by 2030 based on its REmap reports (IRENA, 2015b). Remap scenario of 2030 is based on different technological options assessed by various sources and experts, taking into account the different substitution costs of different technology. In short, comparing the estimation of potential in different sources, there is a risk of our calculations overestimating the solar PV potential, specifically for Poland.

For solar, there are several important limitations that need to be considered. First, the amount of irradiation is lower in northern countries compared to the southern countries. However, for countries under study, the amount of achievable production from solar is reasonable and quite comparable to Germany. Besides, in northern countries the air temperature is lower, which increases the net yield as semiconductors function more efficiently.

Another important limitation is the grid capacity, which can become an issue and must be taken into account in the case of a significant increase in solar production. However, we have assumed that the target countries are able to produce to the benchmark level, i.e. $7.2 \%$ of electricity from solar PV by 2030. 


\subsubsection{Net abatement potential}

The estimated amount of solar power above the baseline is about $27 \mathrm{TWh}$ in 2030; the majority of this comes from Poland and Ukraine (14 TWh and 11 TWh respectively). The contribution of the Baltic States is more modest: about 2 TWh above baseline in total.

As we do not have projections for $\mathrm{CO}_{2}$ intensity of electricity at the country level for 2030, we have used the regional level of $\mathrm{CO}_{2}$ intensity of electricity (Eastern Europe) by 2030 (0.607 $\mathrm{Mt} \mathrm{CO}_{2} / \mathrm{TWh}$ ) (IEA, 2015).

The net abatement potential totals to about $16 \mathrm{Mt} \mathrm{CO}_{2} \mathrm{eq}$, of which the majority is derived from Poland and Ukraine (9 and $6 \mathrm{Mt} \mathrm{CO}_{2}$ eq respectively) (Table 8). In relative terms, the abatement potential as share of 2030 projected emissions is the highest in the Baltic countries: $3 \%$ for Estonia, 3.3\% for Latvia and 3.4\% for Lithuania. For Poland, the share in GHG emissions is $2 \%$ and for Ukraine it is about $1 \%$.

Table 9: The target countries' abatement potential in 2030 ( $\mathrm{Mt} \mathrm{CO}_{2} \mathrm{eq}$ and \% in 2030 emissions)

\begin{tabular}{lrr} 
Country & Mt $\mathrm{CO}_{2} \mathrm{eq}$ & $\begin{array}{r}\text { \% of 2030 emissions of } \\
\text { respective country }\end{array}$ \\
Estonia & 0.41 & 3.0 \\
Latvia & 0.33 & 3.3 \\
Lithuania & 0.59 & 3.4 \\
Poland & 8.83 & 2.4 \\
Ukraine & 6.49 & 0.9 \\
Total & 16.65 & \\
\hline
\end{tabular}

\subsubsection{Abatement costs}

Similar to the Green to Scale study, we used the unit costs of McKinsey cost curve adjusted to 2017 values in EUR. This ensures consistency and comparability with previous studies. Hence, the unit cost used in this study is $23 \mathrm{EUR} / \mathrm{tCO}_{2}$ eq by 2030 . As in the case of wind power, the cost of solar power is expected to decrease in the coming decades, but it is affected by different factors. For example, capital costs related to solar have very strong implications for costs (Fraunhofer ISE, 2015). Total abatement costs for solar power are EUR 390 million in 2030 (Table 9).

Table 10: Abatement cost for solar power in 2030 (in 2017 EUR) 


\subsubsection{Important enablers}

The major enabling factors to drive solar power towards wider deployment are reductions in prices of solar technology, shortening payback time of $\mathrm{PV}$-panels and the EU directive on the energy performance of buildings (2010/31/EU). To meet the directive requirements for the construction of nearly zero-energy buildings, the minimal energy required has to be produced from renewable sources on-site or nearby. In Ukraine, the corresponding law on energy efficiency of buildings which correlates with the EU standards was adopted by the Parliament in 2017.

Renewable power generation costs, including costs for solar, continue to fall and are already competitive enough to meet the needs for new capacity. For example, solar PV module costs have fallen by about four fifths, making residential solar PV systems as much as two thirds cheaper than they were in 2010 (IRENA, 2018).

Financial incentives can act as an efficient enabler of investments, especially when the costs of solar panels are high. In addition, selling the photovoltaic electricity to grid is financially stimulating for prosumers, i.e. private persons as well enterprises which have installed the solar capacities and are consuming part of the generated electricity. For households, net metering is a policy to foster private investment in PV systems, which is used in most of the target countries. Currently a new solution is being worked out in Latvia to make connecting PV-panels to the grid more attractive. Under discussion is the shift in support mechanisms from feed-in tariff to feed-in premium. Estonia is using a feed-in premium scheme, which stimulates smart use of prosumer's generated electricity. Ukraine has a green tariff policy, which is a feed-in tariff scheme for electricity generated from renewable energy sources. Similar to wind energy, competitive procurement, including a tendering system for PV installations, has shown to significantly reduce costs of solar projects in Europe.

In Germany, the benchmark country, renewable energy cooperatives have played a major role in the development of electricity production from photovoltaics and they are said to increase public acceptance of the energy transition (Herbes et al. 2017). This growth has resulted largely from Germany's feed-in tariff system, from which Germany is now transitioning away to a tendering system (ibid.).

From a technical side, a relevant enabler is advanced energy storage capacity which would balance variable supply and demand of solar energy, as well as reduce the need for non-renewable (nuclear, fossil fuelled) power plants standing by to backup renewable energy. The combination of solar power stations with wind parks would also provide more continuous energy generation than either of them alone because of different peak operating times of the day and year.

Finally, capacity for technical assistance and information dissemination are needed. For large-scale photovoltaic systems, intensity of solar radiation, orientation and slope, nearby population, proximity to the electricity grid and accessibility to roads have been identified as the most relevant suitability factors for the exploitation of solar energy (Castillo et al. 2016). 


\subsubsection{Possible barriers}

High upfront investment cost is still often considered to be the main barrier for solar power - purchasing of solar panels is capital intensive and may not yet be affordable without subsidies. In order to reduce this barrier, for example, Estonia plans to launch a support scheme in 2018 which will be targeted at apartment and energy associations, local governments and other potential small producers of solar energy outside of the two largest cities.

The need for grid reinforcement and modernisation can also be a technical or financial impediment for developers. Similarly, connection of small distributed generators and prosumers to the power grid requires financial resources. Grid capacity in the target countries could be a problem for solar and other renewable power generation as further penetration depends on building additional local grids and also, interconnections.

Finding a suitable land for solar farm needs time and spending on planning procedure. In the case of rooftop solar panels in cities, it can be difficult to change already adopted spatial plans in order to achieve the highest solar power productivity which depends on the orientation of panels. Thus, for small generators bureaucracy in permitting phase can be a challenge.

\subsubsection{Major co-benefits}

PV-panels do not emit pollutants during electricity generation and thus positively impact local air quality and public health, in contrast with fossil fuel power plants. Distributed power generation increases energy security and grid resilience.

Using solar PV to power mini-grids is an efficient way to bring electricity to people who reside farther from power transmission lines and thus solves the current problem of power supply in some rural areas.

Reductions in the prices of solar technology bring economic benefits to entrepreneurs and prosumers. For example, in Estonia many rural enterprises - farms and other small-scale productions - have started to build solar power plants in order to reduce the energy cost of their final products. This trend can be observed in the other target countries as well. Like wind parks, PV panels have low operating and maintenance costs.

The combination of solar power stations with wind parks could create in longer term new opportunities for hydrogen energy based power generation via hydrogen storage technologies. By converting the surplus electricity into hydrogen, it can be possible to convert hydrogen back to electricity when the renewable source is not available, or use excess hydrogen for heating buildings, transportation and other purposes. 


\subsubsection{Policy recommendations}

Given the above mentioned drivers of success in the benchmark country and the key enablers and barriers, the following policy recommendations are made:

- Setting clear and more ambitious goals for renewable energy and outlining the expected role of solar PVs;

- Making sure that transmission system operators (TSOs)/distribution system operators (DSOs) remove technical barriers for further solar energy development and investments into grid reinforcement and modernisation;

- Providing financial incentives and improved support schemes, including information dissemination and technical assistance, for micro-generation of solar power: private persons, apartment and energy associations and other small-scale users in urban and rural settlements;

- Implementing pro-consumer approach to scale-up the massive involvement of prosumers (private persons and businesses) by:

- Establishing favourable legal system for electricity production for own consumption and selling the rest to national grid;

- Simplification of the grid connection procedures. All grid connection procedures should be able to be performed in approximately one month or less.

\subsection{Energy efficiency in industry}

\subsubsection{Description of the solution}

In China, the benchmark country, mandatory energy conservation target-setting policy for large energy users included a special programme which covered two thirds of China's total energy consumption. Under a contract signed with the government, participants in the programme were required to meet certain energy saving targets and implement energy management, including establishing energy measurement and management systems, submitting regular energy use audits and developing energy conservation plans. The government and third party service companies organised capacity building events and some companies also set up their own training systems. Public finance support (central and provincial levels) and stimulated private investment were used to enable energy conservation and upgrading of operations. Targets under the programme were disaggregated to local provinces and cities, to make a targetsetting process clearer (Ecofys, 2015). 


\subsubsection{Scale-up method and baseline}

A scale-up scenario in the industry sector is based on a Chinese example where the overall energy consumption is reduced by $10 \%$ within Top 10,000 Energy-consuming Enterprises Program. For our target countries, as no differentiation based on energy consumption of enterprises was possible, $10 \%$ of total industrial energy consumption was used as scale-up scenario. Energy consumption and $\mathrm{CO}_{2}$ emissions data is based on EU and IEA databases (European Commission 2016 \& IEA 2017). Power and heat consumption in the industrial sector is taken into account as industrial sector emissions.

The baseline scenario is based on the EU Reference scenario 2016 (Energy, transport and GHG emissions trends to 2050), where the energy consumption of industrial sector is increasing in all focus countries. The only exception is Ukraine, where trends show a long term decrease of the industrial sector due to the economic recession and the ongoing conflict in the east (German Advisory Group Ukraine, 2014 \& 2016).

\subsubsection{Net abatement potential}

In terms of net abatement potential, the total energy efficiency in industry solution would bring abatement of $24.5 \mathrm{Mt} \mathrm{CO}_{2}$ eq. The largest abatement in absolute terms is in Poland (16 Mt $\mathrm{CO}_{2}$ eq), followed by Ukraine (about $6 \mathrm{Mt} \mathrm{CO}{ }_{2}$ eq). In the Baltics, the abatement potential is lower in absolute terms (about $1 \mathrm{Mt} \mathrm{CO}_{2}$ eq in individual countries), but is higher in relative terms ( $10 \%$ of 2030 national emissions for Estonia, and $3-4 \%$ for Latvia and Lithuania). In Poland, energy efficiency in industry would mean $4 \%$ decrease of GHG emissions in 2030 and in Ukraine about $1 \%$.

Table 11: The target countries' abatement potential 2030 ( $\mathrm{Mt} \mathrm{CO}_{2} \mathrm{eq}$ and \% in 2030 emissions)

\begin{tabular}{lrr} 
Country & $\mathrm{MtCO}_{2} \mathrm{eq}$ & $\begin{array}{r}\text { \% of 2030 emissions of } \\
\text { respective country }\end{array}$ \\
Estonia & 1.40 & 10.2 \\
Latvia & 0.34 & 3.4 \\
Lithuania & 0.64 & 3.7 \\
Poland & 16.36 & 4.4 \\
Ukraine & 5.71 & 0.8 \\
Total & 24.45 & \\
\hline
\end{tabular}

\subsubsection{Abatement costs}

Abatement costs are based on a greenhouse gas abatement cost curve 2030 for Russia adjusted for PPP. As there were no cost estimations available for the target countries of this study, Russian cost figure was estimated as the best available proxy: the buildings and industrial energy consumption are quite similar in these countries. 


\begin{tabular}{lr} 
Estonia & -27 \\
Latvia & -24 \\
Lithuania & -22 \\
Poland & -20 \\
Ukraine & -12 \\
Total & -450 \\
\hline
\end{tabular}

\subsubsection{Important enablers}

For improving the performance of energy efficiency in industries, knowledge, skills and awareness play a key role which can be promoted by training programmes, capacity building events, guidelines and energy audits. Collaboration with experts can help the companies to identify the unused energy saving potential and cost-efficient measures for realizing this potential, bringing along monetary savings.

If the required investment costs are large, public finance support can help industries to overcome financial barriers. But also supporting innovation initiatives is a means to improve industrial energy efficiency. Investment support in industries to promote energy efficiency and reduce energy use is available from EU Funds programming period 2014-2020 in the Baltic States and Poland.

For large energy users, mandatory energy audits should be in place, as stipulated by the EU Directive 2012/27/EU, together with a position for energy managers and energy conservation targets. Expressing energy efficiency as a priority in their business strategy enables companies to manage energy strategically.

Poland has chosen a market-based instrument White Certificate System to implement the EU Directive 2012/27/EU on energy efficiency and introduces Energy Service Company (ESCO) approach for industries. White certificates are issued by the Energy Regulatory Office to suppliers of electricity, heat and gas fuels based on projects savings in the tendering procedure. The companies which do not receive the certificates are required to pay compensatory fees (MURE Database, 2018).

\subsubsection{Possible barriers}

The main barriers which can impede the industries to address energy efficiency are related to capital constraints, lack of effective policy, motivation or awareness/knowledge. According to a recent study in Ukraine, the industrial firms assessed the following as the main barriers to energy efficiency improvements: lack of government policies to support energy efficiency, high upfront investments and higher costs of capital since financial institutions perceive energy efficiency investment as risky and charge a high premium (Timilsina et al. 2016). For Ukraine, an extra barrier is the fact that many energy-intensive industrial facilities are 
located in the two eastern regions, now controlled by Russian-backed forces (Antonenko et al. 2018).

Failure to recognize non-energy benefits of efficiency can act as a motivation barrier. Similarly, low energy prices do not motivate investments and volatile energy prices create uncertainty in investment returns. Even if the financial support instruments are available, they need to be attractive for industries and accessible to SMEs.

Energy consumption trends show that energy use of industry sector is more dependent on economic cycles than energy efficiency policies. Future estimations show that emissions from industrial processes are very difficult to mitigate with current technologies. Deep emission reductions require new technologies and solutions.

\subsubsection{Major co-benefits}

Reduced use of fossil fuel based energy improves air quality, which in turn results in significant positive health impacts. The latter can occur in avoided premature deaths, as it has been the case in China (Ecofys, 2015).

Energy efficiency measures can help industries to enhance their productivity, become more competitive via energy and cost saving as well as create additional employment through greater demand for the occupations involved in the identification and implementation of measures and in the development of relevant equipment. Manufacture and installation of energy efficient equipment and materials is a relatively labour-intensive activity that has the potential to boost local labour markets. Energy efficiency measures are widely seen in the literature as creating more jobs than new energy generation, which tends to be much more capital intensive (Cambridge Econometrics, 2015).

\subsubsection{Policy recommendations}

Given the above mentioned drivers of success in the benchmark country and the key enablers and barriers, the following policy recommendations are made:

- Setting ambitious economy-wide and sectoral energy efficiency targets;

- Awareness raising and training of industry managers on EU Directive 2012/27/EU on energy efficiency. Promotion of the ISO 50001 standard on energy management and EMAS on environmental performance would help achieve energy efficiency objectives;

- Identification and support of additional measures to go beyond low hanging fruits in efficiency investments. Technical assistance programme with an outreach campaign can support evidence-based planning of energy efficiency measures, identification of their cost-efficiency and energy saving potential through regular audits, advisory services and benchmarking; 
- Continuing or establishing simple support measures for SMEs, such as guidance, technical assistance, capacity building, subsidies for energy audits, and supporting networks of SMEs on energy efficiency benefits;

- Establishing guarantee schemes as a financing solution to reduce the risk of local banks in funding energy efficiency measures and to lower interest rates (in Ukraine and possibly in other countries too);

- Imposing the obligation for industry to undergo regular energy audits according to their energy intensity instead of their size (large enterprises as stipulated in the EU Directive 2012/27/EU) could be considered in the EU. 


\section{Transport sector solutions}

\subsection{Electric vehicles}

\subsubsection{Description of the solution}

Battery electric vehicles (EV) and plug-in hybrid vehicles (PHEV) are considered under this solution. The world leader based on the market share of electric vehicles and registered EVs is Norway. In 2017, the total number of EVs in Norway was 141,951 and 67,171 for PHEV (EV Norway, 2018). The total number of cars registered in Norway by the end of 2016 was 2,662,910 (Statistics Norway, 2017), hence the total share of EV and PHEV in the car fleet is about $8 \%$.

The high share of EVs in Norway is due to different reasons, but also including different incentives imposed in Norway. Incentives have existed since 1990 and developed along the way. According to a survey, the most important EV incentive is the tax break which makes the EV price competitive specifically at the time of vehicle purchase. Vehicle purchase price has a stronger effect on users than the total cost of ownership. The progressive car tax system of Norway makes EV models cheaper to buy than similar petrol-run models, which is the main factor for the success of Norway EV market (Haugneland et al. 2017)

If looking at the five target countries in this report, the current share of EVs and PHEVs is very low. If considering the share of EVs in the total car fleet, Estonia has $0.2 \%$ (Estonian Road Administration, 2017). The other studied countries are believed to have an even lower share of EVs in their car fleet.

\subsubsection{Scale-up method and baseline}

As this solution is about the energy use of $E \mathrm{Vs}$, then for the current situation the number of EVs is multiplied by yearly distance driven by them on average. The annual driving distance is related to the car model, climate conditions, etc. The annual driving distance used in Nordic Green to Scale study was 13,000 kilometres, which is the average driving distance of conventional cars. Based on Estonian statistics, the annual driving distance of EVs is about 3,500 kilometres, which is much less than the number used in the Nordic Green to Scale study (13,000 kilometres). For the current situation, the Estonian driving distance figure has been used, but for 2030 we expect the $E V$ to cover the same distance as conventional cars, i.e. the figure based on Norwegian data. The technologies of EVs and PHEVs are developing very rapidly and we expect these to be same in different countries by 2030 (we expect the car models purchased in different countries be more similar than they are now if comparing Norway and the target countries of this report). As for the average energy use per kilometre, we have used the same figure as in Nordic 
Green to Scale ( $0.2 \mathrm{kWh} / \mathrm{km})$. As the proportion of PHEV is small globally and even more in the countries under study, we assume their current share to be 0 . For PHEV in 2030 it is assumed that the average yearly distance driven is 13,000 kilometre and $66 \%$ of the distance is driven using electric power.

The EV share in energy consumption in 2030 is calculated as a share of total consumption of passenger cars in 2030. In the EU reference scenario a decreasing energy use in the transport sector has been estimated for Estonia, Latvia, Lithuania and Poland in 2015-2030 (European Commission, 2016). As these countries have not experienced a decrease in the past, reductions are very unlikely to come about without specific measures to be applied. Even though the vehicles are getting more fuel efficient, private motorization is still increasing. Thus, for baseline we assume the annual average growth to be the same (on average) as it has been in recent years and in the same magnitude as the projected economic growth: $2.5 \%$ annual increase in energy use of passenger cars. The average growth of transport energy use in these countries in $2000-2015$ is between $3 \%$ and $5 \%$ (Eurostat). For Estonia, if a $2.5 \%$ annual increase is used, the resulting baseline for 2030 would be similar to that of the National Development Plan of the Energy Sector (ENMAK 2030+, 2017).

There is a lack of robust data available for the expected share or number of EVs in the target countries in 2030. In the Estonian case, the share of EVs in total mileage is assumed to be $1 \%$ of passenger vehicle-kilometre for EVs and $5 \%$ for PHEVs in 2030 (SEI Tallinn, 2016). Note that this share is based on vehicle-kilometre, not car fleet. In order to make estimations for the energy consumption of EVs and PHEVs, the energy use per kilometre has been taken into account.

As no further information was provided by the country experts, we assume the same modal share for all countries under study. As no data about passenger car vehicle-kilometres was obtained for Ukraine, the baseline figure for this country could not be calculated: it was assumed that energy consumption of EV in Ukraine will be close to zero (if no additional measures are taken). Thus there is a risk that the figure for the potential over baseline for Ukraine is overestimated, but as the abatement figures are not so large, this does not cause severe distortion. For the baseline scenario, by 2030 EVs and PHEVs in the Baltics and Poland use about 340 GWh of electricity, a majority of which comes from Poland (about $300 \mathrm{GWh}$ ) due to the size of the country.

In this report, the solution is about achieving the same share of EVs and PHEVs in car fleet by 2030 as in Norway today. The Nordic Green to Scale study used an additional scenario, which was about achieving the same share of EV in the car sales as Norway is doing at present. This scenario was not applied. The reason was that in the Norwegian example, the results of different incentives are visible in the long run, while EVs have spread substantially quite recently. Hence, we think this scenario of adding the same share Norway's current EVs might be too optimistic in the case of the Baltics, Poland and Ukraine. Under the circumstances of quickly developing technologies and cheaper prices of EVs and PHEVs, the path could be easier now compared to the one of Norway in recent decades. Still, income levels of these countries differ from Norway and price sensitivity has significant implications for this 
solution. We are not optimistic that large changes in buying behaviour will happen overnight. In short, achieving the same share of EVs and PHEVs might slightly underestimate the changes that may come about by 2030, but it is difficult to construct a realistic scenario as it depends on a multitude of factors, which are also discussed in the following subchapters.

\subsubsection{Net abatement potential}

For abatement potential, the energy use of electric vehicles by 2030 has been calculated, and GHG emissions of two options are compared: if this energy use is resulted from power generation or if conventional fuel is used in these vehicles. $\mathrm{CO}_{2}$ emission from power generation is assessed as the Eastern European average (0.607 $\mathrm{MtCO}_{2} / \mathrm{TWh}$ ). The higher energy efficiency of an $\mathrm{EV}$ has also been taken into account following the methodology of Nordic Green to Scale $(0.665 \mathrm{kWh} / \mathrm{km}$ has been estimated for a conventional car and $0.2 \mathrm{kWh} / \mathrm{km}$ for an EV).

The net abatement potential is given in the following table. In total, the net abatement potential is close to $2 \mathrm{Mt}$ of $\mathrm{CO}_{2}$ eq in 2030, with about half coming from Poland. Looking at the abatement potential as a share of respective country projected emissions by 2030; the role for $\mathrm{EV}$ is less than $1 \%$ in all of the targeted countries: $0.1 \%$ for Ukraine, $0.3 \%$ for Poland, $0.4 \%$ for Estonia and $0.7 \%$ for Latvia and Lithuania.

The abatement potential could be higher in these countries if green electricity were used in EVs. This is specifically true for Estonia and Poland, where carbon intensity of electricity production is very high and hence substituting conventional cars with EV does not have the desired effect if electricity mix does not change. However, as it requires additional policy measures not part of this solution to implement, this potential is not calculated. Presumably, the abatement potential would be about two times higher.

Table 12: The target countries' abatement potential in 2030 ( $\mathrm{Mt} \mathrm{CO}{ }_{2} \mathrm{eq}$ and $\%$ in 2030 emissions)

\begin{tabular}{lcr} 
Country & $\mathrm{Mt} \mathrm{CO}_{2} \mathrm{eq}$ & $\begin{array}{r}\text { \% of 2030 emissions of } \\
\text { respective country }\end{array}$ \\
Estonia & 0.06 & 0.4 \\
Latvia & 0.07 & 0.7 \\
Lithuania & 0.12 & 0.7 \\
Poland & 1.06 & 0.3 \\
Ukraine & 0.51 & 0.1 \\
Total & 1.82 & \\
\hline
\end{tabular}

\subsubsection{Abatement costs}

Similar to the Green to Scale study, the unit costs of McKinsey cost curve adjusted to 2017 values in EUR were used. EV unit costs of $132 \mathrm{EUR} / \mathrm{tCO} \mathrm{C}_{2}$ and PHEV costs of $28 \mathrm{EUR} / \mathrm{tCO}_{2}$ (in 2017 values) result in a $105 \mathrm{EUR} / \mathrm{tCO} \mathrm{CO}_{2}$ weighted average value. The unit cost of this solution is the highest among the studied solutions. The abatement costs for obtaining such EV and PHEV sales by 2030 would be EUR 190 million. 


\subsubsection{Important enablers}

The Global EV Outlook 2017 highlights four major groups of policy support mechanisms for electric car deployment: support for the research and development of innovative technologies; targets, mandates and regulations; financial incentives; and other instruments (primarily enforced in cities) which allow increases in the value proposition of $E V s$ (OECD/IEA, 2017). An equally important factor for increasing the share of $E V s$ is an infrastructure and distribution system for electricity: convenient charging locations, the interoperability of the charging system and a well-functioning electricity grid. In Estonia, a country-wide quick charging network has been available since 2013.

In the long run, research support is needed to achieve performance improvements together with a decrease in cost (e.g. battery capacity and range of EVs, shorter recharge times) to scale-up production. In the short term, financial incentives and economies of scale are relevant for cost reductions. Most of the EVs in Estonia have been bought with the support of Estonian Electromobility Programme which compensated up to $50 \%$ of purchase costs to the buyer, the grants were provided from 2011 to 2014 .

Targets, mandates and regulations provide a clear signal to vehicle manufacturers and customers. For example, in Poland, a new Electro-Mobility Act aims for 1 million EVs on-roads by 2025 .

Targeted policies at the municipal level to reduce the level of emissions cities can use a variety of instruments: permission to drive in bus lanes, restrictions on diesel vehicles or on all combustion engines, exemptions of EVs from usage fees for specific portions of the road network (e.g. parking fees, road tolls, etc.), free parking in city-owned charged parking lots. With regard to bus lane use for EVs, this is allowed in the Baltic States, and will be soon available in Poland, according to its Electro-Mobility Act as well as in Ukraine, according to the plans of the Ministry of Infrastructure.

Public demand for clean air and pollution reduction can be a major driver for these policies, while public procurements for electric vehicles can lead by example as well as drive price reductions. Also, information instruments on EVs, fuel savings, operations and maintenance costs are necessary for consumers.

The Nordic experience has shown that flexible, clean and affordable electricity from an integrated electricity market is crucial for the wide deployment of electric vehicles (Korsbakken \& Aamaas, 2016). The authors also point out that the high tax level for conventional vehicles has made it easier to incentivize EV and PHEV purchases because it has meant foregoing tax revenue rather than actively subsidizing sales. Furthermore, Nordic income levels are relatively high and emerging technologies are rather quickly adopted by consumers. 
Norway, which is paving the way for the transition to zero emission electric cars, has developed a substantial package of incentives including: no purchase taxes (1990), low annual road tax (1996), no charges on toll roads or ferries (1997 and 2009), free municipal parking (1999, now decided locally), 50\% reduced company car tax (2000), exemption from $25 \%$ VAT on purchase/leasing (2001 and 2015), access to bus lanes (2003) (Haugneland et al. 2017).

\subsubsection{Possible barriers}

For consumers the purchase price of EVs is still high, which do not attract new buyers without economic incentives, although rapid technological development has taken place and battery costs are falling. Another consumer concern is the driving range of an EV - distance of travel after recharging battery.

For a country, technology shifts are capital intensive due to the need to build charging stations of a sufficient density and geographical coverage.

While Norway has a high tax on vehicle purchases and on fuels, countries with lower taxation levels on vehicles might have fewer options to incentivize EVs, and may have to use less politically convenient policies and measures (Korsbakken \& Aamaas, 2016). In the target countries, there were few or no financial incentives available until 2018, however, since then more are being planned or implemented. The Estonian government is discussing the option to restore some support for the EVs. Tax incentives are foreseen in the Polish Electro-Mobility Act, adopted in February 2018. In Latvia and Lithuania, there are some registration and ownership tax incentives available for EVs (EAFO, 2018). Since 2018, electric cars in Ukraine are exempt from value added tax and imports of electric cars are exempt from excise tax until 2023.

Another factor limiting the wider introduction of EVs in a country can be different charging plug standards which fast charging infrastructures in different countries are compliant with. For example, in Estonia the fast charging network corresponds to standard CHAdeMo, while in the EU the mandatory standard for new fast charging stations is Combo 2. In Latvia, where 150 electric vehicle charging stations will be installed by 2020, the stations will provide Combo 2 and CHAdeMO type plugs. In Lithuania, construction of more charging stations along the main roads is under discussion as well as in Poland and Ukraine, where the further development of public charging network is foreseen.

\subsubsection{Major co-benefits}

A high share of electric vehicles in national car fleet contributes to cleaner air and lower noise level in cities. Health and associated cost benefits from reduced emissions of local pollutants, less smog and noise have a particular importance in larger cities.

Economic benefits are realised in the reduced total energy demand when vehicles are converted from internal combustion engines to EVs. National energy security will improve through increased energy efficiency and lower dependency on imported fossil fuels as well as through using EV batteries as storage equipment. 
By charging EVs during the night when storing electricity produced by wind turbines is difficult, the batteries act as temporary storage in the power grid. Furthermore, when EVs are not in use, but connected to a power outlet, they can give some of their battery power back to the grid in case the power demand increases. Thus batteries can operate to balance the power grid.

\subsubsection{Policy recommendations}

Given the above mentioned drivers of success in the benchmark country and the key enablers and barriers, the following policy recommendations are made:

- Fuel taxes and motor-vehicle taxation have to take into account the carbon dioxide $\left(\mathrm{CO}_{2}\right)$ emissions. The differences between tax rates based on the vehicle's carbon dioxide emissions need to be large enough to influence the car purchase decision;

- Considering additional tax policies, e.g. deduction of VAT, to promote purchase of all kinds of electric vehicles by private persons, public and business sectors;

- Integration of scaling up the EVs into national transport strategies and action plans;

- Continuing investments in the development of the public EV charging infrastructure, taking into account compatibility to prevalent charging standards;

- Setting the targets for public sector EV fleet and favouring EVs by public procurement policies, e.g. including respective criteria in procurements for the vehicle fleets of public authorities and public transport.

\subsection{Biofuels in transport}

\subsubsection{Description of the solution}

Biofuels or fuels made from biomass are seen as options for mitigating climate change, decreasing urban air pollution and developing rural areas. However, this solution has also been criticized for competing with land used for food production and for biodiversity conservation as well as for not being carbon neutral in all circumstances. The availability and origin of biofuels is not a topic for this report, here it is assumed that the biofuels needed are available in a country or it is possible to import the necessary amounts.

While in the Nordic Green to Scale report, Finland and Sweden are used as two different benchmarks, in this report Sweden, which has focused on bioethanol as a transport fuel, is used as the benchmark. The biofuel penetration in Finland is only modestly over the current target of EU of $10 \%$ of biofuels in transport sector, which is mandatory to four of the countries under analysis. Thus, taking more ambitious benchmark of Sweden would bring higher additional abatement potential. The degree of implementation is calculated as the share of energy from biofuels in the total final energy consumption of transport. 


\subsubsection{Scale-up method and baseline}

For the reasons described above, Sweden has been used as benchmark of this solution. In 2016, the share of biofuels in road transport in Sweden was $18.5 \%$.

It was assumed that as the baseline for 2020, the share of biofuels in the Baltic countries and Poland will be $10 \%$ (EU target) and $2 \%$ in Ukraine. We assumed these biofuels to meet sustainability criteria, but we did not assume them to be advanced biofuels in the meaning of the Renewable Energy Directive. For 2030, no further change in the EU countries and increase up to $4 \%$ in Ukraine (global assumption) were assumed. The figures from the EU Reference Scenario were used for energy consumption forecasts for the EU member states (European Commission, 2016). For Ukraine, the country expert's estimate was used for the baseline transportation fuel consumption.

The range of $30-90 \%$ (mid value $60 \%$ ) has been proposed by IPCC as the net abatement effect of replacing fossil fuels with biofuels (Sims et al., 2014). For the calculations in the current report the mid value $(60 \%)$ and $2.83 \mathrm{~kg} \mathrm{CO}_{2}$ per litre as the emission factor of conventional fuel was used.

\subsubsection{Net abatement potential}

The net abatement potential is given in the following table. In total biofuels in transport would bring the region an abatement potential of $8 \mathrm{Mt} \mathrm{CO}_{2} \mathrm{eq}$, the largest contribution coming from Poland and Ukraine (both close to $4 \mathrm{Mt} \mathrm{CO}_{2} \mathrm{eq}$ ). In relative terms, highest abatement as a share of $2030 \mathrm{GHG}$ emissions is in Latvia and Lithuania (about 2\%). The biofuels in transport would mean decrease of about $1 \% 2030$ GHG emissions in Estonia, Poland and Ukraine (Table 13).

Table 14: The target countries' abatement potential in 2030 ( $M t \mathrm{CO}_{2} \mathrm{eq}$ and \% in 2030 emissions)

\begin{tabular}{lcr} 
Country & $\mathrm{Mt} \mathrm{CO}_{2} \mathrm{eq}$ & $\begin{array}{r}\text { \% of 2030 emissions of } \\
\text { respective country }\end{array}$ \\
Estonia & 0.14 & 1.0 \\
Latvia & 0.21 & 2.1 \\
Lithuania & 0.28 & 1.6 \\
Poland & 3.63 & 1.0 \\
Ukraine & 3.87 & 0.6 \\
Total & 8.13 & \\
\hline
\end{tabular}

\subsubsection{Abatement costs}

Total abatement costs were based on McKinsey global model, adjusted for country specific figures by applying the purchase price power index from International Monetary Fund. 


\begin{tabular}{|cccccc} 
& EST & LAT & LIT & POL & UKR \\
\hline Unit abatement cost, EUR/tCO2 & 1.47 & 1.34 & 1.22 & 1.09 & 0.65
\end{tabular}

Table 16: Abatement cost for biofuels in transport in 2030 (in 2017 EUR)

Note: McKinsey global abatement cost.

\subsubsection{Important enablers}

EU targets and mandates for blending and producing fuel from advanced biofuels in transport sector set the goals and directions for the target countries. There are no specific biofuel targets for biomethane and liquid biofuels in these countries, besides the EU $10 \%$ renewable energy target in the transport sector by 2020 (REN21, 2017). Mandatory blending requirement for biofuels has been established in Latvia, Lithuania and Poland; in Estonia it will start only in May 2018. Ukraine is intending to adopt a law on obligatory blending of biofuels with the gasoline and diesel with respect to EU practice.

Technology improvements for second and third generation biofuels that do not rely on land grown crops (agricultural residues, timber-processing and forest residues, municipal waste, etc.) would enable countries to achieve commercial-scale production and reduced prices of advanced transport biofuels. Government incentives are relevant in the long-run for their research and development.

Existence of sustainable and effective agricultural and forestry supply chains and a well-functioning local biofuel market also constitute important enablers for competitive biofuel production. From the target countries, local liquid biofuel is currently not produced in Estonia. Ukraine does not produce biofuels in the relevant volumes. Much of the bioethanol production in Central Europe is made from imported corn from Ukraine (USDA, 2017).

The leading countries in this field - Finland and Sweden - have reached relatively high shares of biofuels in road transport due to blending obligations and taxation (Korsbakken \& Aamaas, 2016). In particular, Finland is one of the leaders in producing advanced liquid fuels from lignocellulosic sources, resulting from state support for biofuels in combination with huge forests and a highly innovative forest industry (IEA Bioenergy, 2012). 


\subsubsection{Possible barriers}

Biofuel is carbon neutral only if biomass growth exceeds biomass burning in the whole life cycle and even then it is carbon neutral only over long periods of time (the length depends on the feedstock). First generation biofuels, i.e. crops which compete with food crops for agricultural land can produce more emissions than they avoid if cultivation, including deforestation and soil acidification, is taken into account. Additional negative effects may result from land use change and the loss of biodiversity. The performance of biofuels depends on the choice of feedstock, the way the land is used, and the energy and fertiliser inputs that are required (IEA Bioenergy, 2012).

For advanced biofuel production, the availability of raw materials which meet sustainability criteria may be limited due to natural conditions or economic decisions. Besides, in a growing bio-economy, there are sectors which will compete for the scarce resources of biomass, both for domestic uses and exports, such as energy for heat, power and fuel, building materials, packaging, plastic-replacements, pharmaceuticals.

Current high prices for local biofuels make it difficult for renewable energy technologies to compete with imported biofuels or fossil fuels if there is lack of economic instruments and support for biofuels technology development. This was the case, for example, in Latvia and Lithuania where a reduction of prices for conventional fuels in 2014 made biofuels less competitive. In addition, other EU producers offered biocomponents for blending with more competitive prices than local producers (USDA, 2016).

\subsubsection{Major co-benefits}

Socio-economic benefits arise with the reduced dependency on imported fossil fuels, while limiting the need for new technology (biofuel solution is to some degree compatible with the internal combustion engine in current vehicles). Biofuel production supports local economy by creating new jobs and opportunities for agricultural producers and forest related industries, in addition to increasing national energy security.

Environmental benefits appear with second generation bioenergy crops, such as short rotation coppice, which can reduce nitrate leakage into water supplies-a common problem for agricultural land treated with nitrogen-based fertiliser. These crops also improve soil quality, increase the amount of carbon sequestered in the soil, and reduce soil erosion (Rowe et al. 2009).

\subsubsection{Policy recommendations}

Given the above mentioned drivers of success in the benchmark country and the key enablers and barriers, the following policy recommendations are made:

- Limiting eligibility for support to those sustainable feedstocks which are most likely to reduce net carbon emissions; 
- Assessing the availability and quantities of sustainable raw material for advanced biofuels with the highest GHG emission saving potential in each target country. In order to achieve cost-effective production of fuel from wastes and residues, regional cooperation may be needed;

- Differentiating fuel taxes based on $\mathrm{CO}_{2}$ emissions, which would give advantage to biofuels, and phasing out support for biofuels from purpose-grown crops. For production and consumption of liquid biofuels, government policies must ensure that the required raw materials are produced in a sustainable way from feedstock which reduces net carbon emissions;

- Increasing the mandatory blending requirement for advanced biofuels based on transport fuel energy content in the EU, associated with adequate requirements to sustainability in sourcing of biomass. 


\section{Solutions for buildings and households}

\subsection{Energy efficiency in buildings}

\subsubsection{Description of the solution}

A large share of the Eastern Europe dwellings was built during the industrialisation construction period in the Soviet Union and Poland in 1960-1990. These buildings have significant heat losses due to insufficient insulation of building envelope. In addition to low energy efficiency levels, common problems also include insufficient ventilation, uneven indoor temperatures and insufficient thermal comfort.

Governments in EU countries have focused on improving energy efficiency in buildings. There are regulations for energy efficiency of buildings with requirements for new buildings, nearly zero energy buildings (nNZB) and for major renovation in the EU. Also, regulations and standards for energy efficient lighting, requirements for ventilation systems and household appliances are implemented. Nevertheless, moderate growth in home sizes and the number of individual households/detached houses, considerable expansions of total commercial floor space and an explosion in electronic appliances have still led to a steady growth in total energy consumption in buildings of close to $1 \%$ per year (IEA/NCM, 2016).

However, Sweden is the only Nordic country where also the absolute energy consumption in buildings has declined, by close to $1 \%$ per year, despite the growth in economy, population and building mass. This has been a result of dedicated set of policies like high energy efficiency requirements, advice and awareness raising and also importantly due to procurement groups who jointly procure more energy efficient solutions/technologies.

\subsubsection{Scale-up method and baseline}

Current trends in energy demand in buildings show an increase of approximately $1 \%$ per year. However, the scale-up scenario in the buildings sector is based on the Swedish example, where overall energy consumption is reduced by $1 \%$ per year. Energy consumption and $\mathrm{CO}_{2}$ emissions statistics are based on EU and IEA databases. The baseline scenario is based on the EU Reference scenario 2016 (Energy, transport and GHG emissions Trends to 2050), which shows that the energy demand of the building sector will not reduce. 
Emissions of the building sector are directly linked to the power and heat generation. In order to avoid double accounting for emissions savings, the buildings energy efficiency scenario does not take the lowest possible power and heat production into account. Those emission reductions are taken into account in the CHP scenarios.

\subsubsection{Net abatement potential}

Energy efficiency in buildings has the highest abatement potential among analysed solutions: in total it is about $53 \mathrm{Mt} \mathrm{CO}_{2}$ eq. In absolute terms, the largest contributors are Poland ( $26 \mathrm{MtCO}_{2}$ eq) and Ukraine (about $25 \mathrm{MtCO}_{2}$ eq). In relative terms, as a share in projected GHG emissions by 2030, energy efficiency in buildings is the solution with highest abatement potential in Estonia, Latvia, Poland, Lithuania and lastly in Ukraine: in Estonia it could decrease $9 \%$ of 2030 emissions, in Latvia $7 \%$ and Poland $7 \%$, in Lithuania $5 \%$ and in Ukraine 4\%. (Table 15).

Table 17: The target countries' abatement potential in 2030 ( $\mathrm{Mt} \mathrm{CO}_{2} \mathrm{eq}$ and \% in 2030 emissions)

\begin{tabular}{lrr} 
Country & Mt $\mathrm{CO}_{2} \mathrm{eq}$ & $\begin{array}{r}\text { \% of 2030 emissions of } \\
\text { respective country }\end{array}$ \\
Estonia & 1.28 & 9.3 \\
Latvia & 0.72 & 7.1 \\
Lithuania & 0.87 & 5.1 \\
Poland & 26.09 & 7.0 \\
Ukraine & 24.71 & 3.6 \\
Total & 53.68 & \\
\hline
\end{tabular}

\subsubsection{Abatement costs}

Abatement costs are based on the greenhouse gas abatement cost curve 2030 for Russia and PPP adjusted. As there were no cost estimations available for the target countries of this study, Russian cost figure was estimated as the best available proxy: the buildings and industrial energy consumption are quite similar in these countries.

Table 18: Abatement cost for energy efficiency in buildings in 2030 (in 2017 EUR)

$\begin{array}{lr}\text { Country } & \text { Cost } \\ \text { Unit abatement cost }\left(\mathrm{EUR} / \mathrm{tCO} \mathrm{CO}_{2}\right): & -89 \\ \text { Estonia } & -81 \\ \text { Latvia } & -74 \\ \text { Lithuania } & -66 \\ \text { Poland } & -39 \\ \text { Ukraine } & -2,917 \\ \text { Total abatement cost (million EUR) } & -217\end{array}$




\subsubsection{Important enablers}

Regulations such as energy efficiency requirements and building codes help the states and municipalities to promote the energy efficiency in buildings. In the EU, the directive 2010/31/EU sets the requirements on the energy performance of buildings. In Ukraine a law on energy efficiency in buildings, correlating with the EU standards, was adopted by the Parliament in 2017. The law establishes the minimal requirements for the energy efficiency of buildings and also implements a mandatory certification system in 2019. However, there are soft obligations and no clear targets in the Ukrainian law.

The most important financial incentives include tax deductions, low interest loans, subsidies and grants. Investment support programmes to increase energy efficiency in buildings for the 2014-2020 EU Funds programming period are available in the Baltic States and Poland. In Ukraine, there are EBRD programmes which provide loans to finance energy saving improvements in residential and public buildings, as well as a government programme to partially compensate the cost of loans. The Energy Efficiency Fund of Ukraine, which was launched in 2018 with the state and EU funds, is expected to co-finance energy efficient modernization of buildings to individuals and legal entities (Interfax Ukraine, 2018).

Information and guidance instruments, such as training, consultation, technical assistance and energy labels are used to increase the know-how of energy efficiency in buildings, mobilise action and shape energy consumption patterns. Compulsory energy labelling of residential and public buildings also inform the real estate market.

Active leadership is needed and positive results of neighbouring apartment associations who have passed the energy efficiency refurbishment can serve as an example to spread the relevant message. According to the Swedish experience, sufficient communication and pilot projects are good means to overcome residents' concerns (Krysiński et al. 2017). In Sweden, information and opportunities for energy efficiency improvements are actively distributed through municipal climate and energy advisors and the Swedish Energy Agency (Korsbakken \& Aamaas, 2016).

There is also room for innovation to realise the energy efficiency gains (e.g. in materials). The model of energy service companies (ESCOs) could offer comprehensive solutions to refurbishment for multi-apartment houses as they propose full service and carry the overall responsibility. However, in the target countries, the ESCO model is not widely spread yet.

\subsubsection{Possible barriers}

One of the main barriers when it comes to energy efficiency measures in buildings is the high dependency on private investments as well as the uncertainties and long payback time for energy savings. Therefore, (low income) residents often tend to prefer single measures instead of comprehensive retrofitting. However, if only partial solutions are implemented, e.g. limited insulation of roofs or walls, it will be very expensive and perhaps technically impossible to realise the full energy-saving potential at a later date. 
In multi-apartment buildings, the negotiations about refurbishment are often complex and the speed of renovation is slow, despite the availability of support schemes. Access to financing is hindered for the whole house in cases where there are empty flats for which utility charges are not paid. Since 2018, the apartment association is the mandatory legal form for managing apartment buildings and blocks of flats in Estonia. However, it remains to be seen how much this will impact the speed of renovation.

Additional barriers include the lack of knowledge about economic gains and possible technologies or low energy taxes which are not an incentive to care enough about energy efficiency measures. In Ukraine, gas prices for both households and municipal heating utilities have traditionally been heavily regulated and subsidized. However, the prices rose steeply in 2016 after Ukraine's commitments to the International Monetary Fund (IMF) (Antonenko et al. 2018).

In a recent Polish study, societal barriers hampering the energy efficient renovations comprised of financial problems, residents' low levels of awareness which led to low demand for energy-efficient solutions, as well as lacking education and promotion of energy efficient solutions (Krysiński et al. 2017).

Finally, if consumption habits do not change, i.e. energy savings from building insulation translate into higher indoor temperatures and other improvements in comfort, such as increasing floor area per capita, the potential for energy efficiency gains will remain unused.

\subsubsection{Major co-benefits}

With energy efficiency measures in buildings, the air quality in the local environment will improve as a result of reduced demand for heating and less fossil energy consumption. The possibility to control the temperature and indoor climate will bring along health benefits to residents.

Cost savings in energy bills imply a reduction in energy poverty and energy efficiency measures help extending the lifespan of buildings. Remarkable decreases in heat consumption will shorten the payback period of investment costs and increase the resale value of the building or apartment. On a state level, the energetic refurbishment of the building stock would help increase the overall social well-being and the reduced demand for energy would lead to a greater security of energy supply.

Additional benefits include the creation or retention of jobs and investments in local companies, thereby benefiting local workers. In a study of economic benefits of renovation of apartment buildings in Estonia it was found that 17 jobs per EUR 1 million of investment in renovation were generated per year (Pikas et al. 2015). Out of these 17 jobs, 10 had been created on the construction site, 1 in the consultancy and 6 in manufacturing industries. Direct tax revenue was between $32-33 \%$, depending on the renovation project (ibid.). 


\subsubsection{Policy recommendations}

Given the above mentioned drivers of success in the benchmark country and the key enablers and barriers, the following policy recommendations are made:

- Providing financial support to multi-apartment building and detached houses for refurbishment and energy efficient heating via targeted support schemes;

- Increasing expert knowledge and the number of energy efficiency experts through state financed schemes;

- Considering instruments to promote better self-organisation of inhabitants in multiapartment buildings, e.g. via mandatory apartment associations in order to form legal body for managing the negotiations, financial resources and construction works related to renovation (is in force in Estonia);

- Establishing or strengthening of an advisory system in order to reach out to apartment associations and homeowners with less know-how and skills. This could include wider information dissemination and guidance instruments (e.g. printed materials);

- Improving monitoring and verification of energy efficiency projects (in Ukraine and possibly in other countries too).

\subsection{Bioenergy for heating}

\subsubsection{Description of the solution}

Bioenergy is largely available in the target countries, as there is quite a substantial area of forest available. In the Nordic Green to Scale study, Finland was used as the benchmark for biomass use in heating. Biomass, mostly in the form of wood residues or pellets, has a large and growing share in many parts of the Finnish energy system. The degree of implementation is the share of biomass used for heating of buildings. However, some of the countries studied in this report have already bypassed the Finnish benchmark. Hence, for these countries the scale-up potential could not be realized (see below for further information).

\subsubsection{Scale-up method and baseline}

The benchmark for this solution is Finland, where $41.7 \%$ district heating in 2015 was produced with biofuels. Since Baltic countries have similar or higher share of biofuel in district heating, abatement potential was estimated only for Ukraine (biofuel share 3.4\%) and Poland (5.1\%). Eurostat data (2015) regarding buildings heat consumption (residential, services, and unspecified other) was used to estimate the share of biofuel in total heat consumption. $\mathrm{CO}_{2}$ intensity $\left(\mathrm{tCO}_{2} \mathrm{eq} / \mathrm{TJ}\right)$ estimate of final heating energy (non-bioenergy) was based on Eurostat data. 
The baseline annual heat consumption growth in urban area was based to EU reference scenario (varies between $0.34 \%$ and $1.74 \%$, depending on a country), and $-0.5 \%$ growth was assumed for Ukraine, based on historic trend line.

\subsubsection{Net abatement potential}

The net abatement potential is given in the following table. In total, bioenergy for heating would contribute $13 \mathrm{Mt} \mathrm{CO}_{2}$ eq as abatement potential (Table 17). The solution is not analysed for the Baltic States where it is already beyond the benchmark case. In Poland, bioenergy for heating would decrease GHG emissions by $9 \mathrm{Mt} \mathrm{CO}_{2}$ eq and in Ukraine by $4 \mathrm{Mt} \mathrm{CO}_{2}$ eq. By comparing the relative importance in $2030 \mathrm{GHG}$ emissions of these countries, the abatement share of this solution is higher for Poland $(2.5 \%)$ and lower for Ukraine (0.6\%).

Table 19: The target countries' abatement potential in 2030 ( $\mathrm{Mt} \mathrm{CO}_{2} \mathrm{eq}$ and \% in 2030 emissions)

\begin{tabular}{lrr} 
Country & $\mathrm{Mt} \mathrm{CO}_{2} \mathrm{eq}$ & $\begin{array}{r}\text { \% of 2030 emissions of } \\
\text { respective country }\end{array}$ \\
Poland & 9.4 & 2.5 \\
Ukraine & 4.0 & 0.6 \\
Total & 13.4 & \\
\hline
\end{tabular}

\subsubsection{Abatement costs}

Similarly to Nordic Green to Scale study, McKinsey marginal cost for Russia was used as unit abatement cost, converted to 2017 EUR value (66 EUR/tCO $\mathrm{CO}_{2} \mathrm{eq}$ ). As there are no cost figures for the target countries of this study, this has been estimated as the closest proxy value for that. In addition, PPP adjustment was made by using IMF's data.

Table 20: Abatement cost for bioenergy in heating in 2030 (in 2017 EUR)

Unit abatement cost $(\mathrm{EUR} / \mathrm{tCO})_{2}$ :

\subsubsection{Important enablers}

Supply of sustainable biomass, which is available within a reasonable distance (forest industry by-products and residues, herbaceous biomass, low-quality wood and shrubbery, agricultural waste, etc.), acts as one of the most important enablers for the large-scale use of bioenergy in heating. In the target countries this potential is rather high and wood pellet production has expanded especially rapidly in the Baltic states (Latvia as the leader, followed by Lithuania and Estonia) (USDA, 2017). In Ukraine, the number of boilers running on straw and other agricultural waste (like maize stalks, 
maize cobs, and sunflower stalks) will likely increase considerably, while the rise in the number of wood-fired boilers will be comparatively limited (IFC, 2015).

Secondly, large-scale application of bioenergy benefits from district heating $(\mathrm{DH})$ systems which provide a market for wood fuels, allow for more flexible use of fuels than small local boiler houses and avoid air pollution. In colder climates, DH systems are increasingly cost-effective and local renewable energy sources lower the price of district heating. For instance, over the last ten years, the average biomass prices for $\mathrm{DH}$ plants in Lithuania (incl. transportation cost and taxes) have been constantly lower than the prices for imported natural gas (Nagevičius, 2017).

Renewable energy support schemes (investment subsidies, feed-in tariffs or premiums for power generated in CHP plants, tradable renewable energy certificates, energy taxation which favours the use of bioenergy, such as carbon pricing for fossil fuels, etc.) are used to facilitate the uptake of biomass. Also in the target countries, biomass use for heating benefits from feed-in tariffs or premiums which is paid to electricity when biomass is fired in efficient CHP plants. Investment support under 20142020 EU Funds programming period is available for biomass boiler plants and to substitute fossil fuel boiler by biomass boiler. Similar support programme exists in Ukraine, to increase the share of biomass in district heating by replacing gas boilers.

$\mathrm{EU} /$ national/municipal targets for increasing the use of bioenergy and on phasing out the use of fossil fuels together with standards for nitrous oxides $\left(\mathrm{NO}_{\mathrm{x}}\right)$, sulphur dioxide $\left(\mathrm{SO}_{2}\right)$ and particulate matter (PM) set the general framework enabling biofuels as an abatement solution. In Finland - the benchmark country - renewable energy policies include the goal of replacing coal in power plants with biomass and energy efficiency measures by 2029. There are also subsidies for biomass use in Finland which have contributed to the high motivation of forestry companies to find ways to turn their waste into profit-making products (Korsbakken \& Aamaas, 2016).

According to the Swedish experience, existence of the district heating systems that provided a market for wood fuels, long-lasting government support for bioenergy research, development and demonstration (RD\&D) on biomass conversion technologies and forestry supply chains have been the key enablers for the expansion of biomass use in Swedish heating systems (Ericsson \& Werner, 2016).

\subsubsection{Possible barriers}

Large increases in bioenergy use can adversely impact ecosystems (incl. forests, biodiversity, soil) if forests are used intensively, agricultural land is converted to produce energy crops or sustainability criteria for biomass are not implemented. Also, the use of wood for heat can release more GHG emissions $\left(\mathrm{CO}_{2}, \mathrm{CH}_{4}\right)$ into the atmosphere during combustion than the fossil fuels it replaces (Brack, 2017). Biomass feedstock can be carbon neutral only if biomass growth exceeds biomass burning in the whole life cycle and over long time period. According to Brack (2017), most likely to reduce net carbon emissions (or have low carbon payback periods) are primarily mill residues, together with post-consumer waste. 
Large-scale production of biomass energy can have harmful effects on health and crop yields via higher level of tropospheric ozone, which depends on the tree types and regions to be used (Beltman et al. 2013). On the local level, burning firewood in small boilers (in particular) contributes to higher levels of air pollutants, such as fine particulate matter (PM2.5) and carbon monoxide (CO), which can cause health problems.

In smaller towns and settlements, the lack of $D H$ network hinders significantly the use of local biomass residues as the construction of heat transmission network (grid) is expensive. Due to relatively low heat demand in these towns and settlements economic efficiency plays its hindering role. Another hurdle for heating energy producers can be the higher price of biomass energy, which makes it difficult to compete with fossil fuels if the latter are subsidised. Barriers related to significant upfront investment and the unstable supply of biomass in required quality were mentioned as the biggest concerns by municipal heat suppliers in Ukraine. This was supplemented by the subsidised price of natural gas for district heating (IFC, 2015).

The availability of wood fuel can be disrupted by low buy-in price which does not motivate forest owners to gather wood residues from cutting areas. In general, the price of wood fuel is affected by the availability of raw material, weather conditions, markets and production volumes. There is also competition with existing and future uses of biomass, such as for food, feed, forest products, transportation fuels, chemicals and plastics, which reduce the availability of sustainably sourced biomass for heating. In cities, there may be an issue of insufficient storage space for biomass if the boiler house or CHP plant was designed for fossil fuels and thus needs additional investment.

\subsubsection{Major co-benefits}

Domestic biomass supply increases the energy security in the heating sector by reducing the dependence on imported natural gas or other fossil fuels. Replacement of imported liquid and gaseous fossil fuels with locally available biomass balances foreign trade, improves the air quality due to reduced sulphur and nitrogen emissions, and has the potential to create employment in the countryside as a result of job opportunities in the forestry and agricultural fuel supply chain, including in transport companies. The job creation estimates vary between different technologies, resulting on average in 0.61 job-years per GWh for a number of biomass technologies (Carragher et al. 2013).

The use of biomass energy is relatively cheap and flexible mode of heating, which could also benefit the forest-related industries by making use of sawmill residues. The pulp and paper industry would benefit economically from burning its waste - black liquor - for energy (Brack, 2017). 


\subsubsection{Policy recommendations}

Given the above mentioned drivers of success in the benchmark country and the key enablers and barriers, the following policy recommendations are made:

- Development and application of country-specific sustainability criteria for solid biomass, which include protection of biodiversity and soil fertility. Restricting eligibility for support to those sustainable feedstocks which are most likely to reduce net carbon emissions;

- Reviewing the tax policy used in district heating in order to stimulate the transition to bioenergy. Providing financial incentives towards wider deployment for fuel switch (from fossil fuels to biomass) in private houses;

- Considering (increase) of feed-in tariff/premium for the electricity produced in biomass fuelled energy efficient CHP plants. 


\section{Agriculture and forestry sector solutions}

\subsection{Reforestation and land restoration}

\subsubsection{Description of the solution}

The benchmark for reforestation and land restoration as a solution is Iceland, which grapples with the problem of soil erosion and degradation. It has been estimated that more than $50 \%$ of Iceland's vegetation cover has disappeared due to erosion since the settlement period. Systematic revegetation and land reclamation began more than century ago with the establishment of the Soil Conservation Service of Iceland. Over the last decades, there have been numerous reforestation projects. The most important afforestation efforts are made on farms and private owned lands with the state support (Icelands's Sixth National..., 2014).

The effect of Iceland's afforestation efforts has been estimated as the share from woodlands before settlement: $1.4 \%$; and in case of land restoration as the share of eroded lands: $0.65 \%$ (Korsbakken \& Aamaas, 2016).

In general, the situation in our target countries is much better than in Iceland as there are not so many degraded lands. The area covered by forests in the target countries is also large, while in Iceland the area covered by forest is $0.5 \%$ of the land area. The respective share is more than $50 \%$ in Estonia and Latvia, about $35 \%$ in Lithuania, 30\% in Poland and 16\% in Ukraine (World Bank, 2018).

\subsubsection{Scale-up method and baseline}

As described above, the benchmark of implementation share is the same as in the report of Nordic Green to Scale (Korsbakken \& Aamaas, 2016). 1.4\% for reforestation (of woodland before settlement) and $0.65 \%$ for revegetation (restoration of degraded lands).

Potential for reforestation and land restoration in our region is based on Nabuurs et al. (2007), which provides information about the potential mitigation of forestry measures by regions at costs equal or less than $100 \mathrm{USD} / \mathrm{tCO}_{2}$. The potential for countries in transition is provided in the following table. The numbers in the table are total numbers for the whole region. 
Source: Nabuurs et al. 2007.

Compared to other regions like Central and South America, Africa, Asia and USA, the region studied in this report is not the region of highest potential. For example, potential of forestry measures in Central and South America is 3,145 $\mathrm{Mt} \mathrm{CO}_{2} / y e a r$, in Africa 1,925 $\mathrm{MtCO}_{2} /$ year and 1,915 $\mathrm{Mt} \mathrm{CO}_{2} /$ year in East Asia. In countries of transition, the potential is $1,685 \mathrm{MtCO}_{2}$.

As the group of countries in transition 5 is much larger than the five target countries under study in this report, we have extracted the share of our target countries' share in this potential based on the share of forested area among this country group. According to World Bank data, these five countries' share of forested area among countries in transition is $3 \%$ (World Bank, 2018), so this proportion of the above mentioned potential is used.

\subsubsection{Net abatement potential}

The abatement potential of the 5 countries under study is $0.24 \mathrm{MtCO}_{2} \mathrm{eq}$, of which $0.23 \mathrm{Mt}$ $\mathrm{CO}_{2}$ eq comes from reforestation and $0.01 \mathrm{Mt} \mathrm{CO}_{2}$ eq from restoration of degraded lands.

As can be seen in Table 20, the largest part of the abatement potential is again resulting from Poland and Ukraine (0.08 $\mathrm{MtCO}_{2}$ eq and $0.09 \mathrm{Mt} \mathrm{CO}_{2}$ eq). Looking at the share in total national emissions of 2030, the potential of reforestation and land restoration is very modest: $0.1 \%$ for Estonia and Lithuania, $0.3 \%$ for Latvia and close to $\mathrm{o}$ in case of Poland and Ukraine (Table 20).

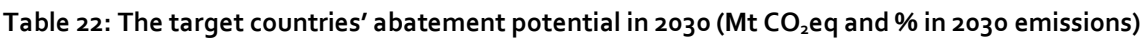

\begin{tabular}{lrr} 
Country & Mt $\mathrm{CO}_{2} \mathrm{eq}$ & $\begin{array}{r}\text { \% of 2030 emissions of } \\
\text { respective country }\end{array}$ \\
Estonia & 0.02 & 0.1 \\
Latvia & 0.03 & 0.3 \\
Lithuania & 0.02 & 0.1 \\
Poland & 0.08 & 0 \\
Ukraine & 0.09 & 0 \\
Total & 0.24 & 0 \\
\hline
\end{tabular}

5 Countries in transition: Croatia, Cyprus, Czech Republic, Estonia, Latvia, Lithuania, Malta, Poland, Russian Federation, Slovakia, Slovenia, Kyrgyzstan, Tajikistan, Armenia, Georgia, Moldova (Republic of), Ukraine, Uzbekistan, Albania, Azerbaijan, Belarus, Bosnia and Herzegovina, Bulgaria, Hungary, Kazakhstan, Macedonia, Montenegro, Romania, Serbia, Serbia and Montenegro, Turkmenistan. 


\subsubsection{Abatement costs}

For abatement costs, similar to the Nordic Green to Scale project, we use the McKinsey cost curve figure adjusted to 2017 values: $16.5 \mathrm{EUR} / \mathrm{tCO}_{2}$ for reforestation and $12 \mathrm{EUR} / \mathrm{t} \mathrm{CO}_{2}$ for land restoration. These should be regarded as rough estimates rather than very precise prices.

The total abatement cost is about EUR 4 million. Hence, the total cost of the solution is rather low compared to the other solutions, but it must be noted that the abatement potential is modest as well.

Table 23: Abatement cost for reforestation and land restoration in 2030 (in 2017 EUR)

$\begin{array}{lr} & \text { Cost } \\ \text { Degraded forest afforestation unit cost }\left(\mathrm{EUR} / \mathrm{t} \mathrm{CO}_{2}\right) & 16.5 \\ \text { Degraded land restoration unit abatement cost }\left(\mathrm{EUR} / \mathrm{t}\left(\mathrm{CO}_{2}\right)\right. & 12 \\ \text { Total abatement cost (million EUR) } & 4\end{array}$

\subsubsection{Important enablers}

The main regulatory measure for reforestation of degraded land is the obligation to reclaim land disturbed by extraction. E.g. in Estonia, the Earth's Crust Act requires the holder of the extraction permit to adjust the land into a wooded area, a body of water, or other type of land having value in use or a landscape of a recognised value, after the use is finished with mining. However, there is also a need to find means for partial restoration of peat extraction areas - exhausted peat fields among extraction areas that have extraction permits, in order to change these fields from land emitting GHGs into removing GHGs.

Important enablers that are required for scaling up the solution are also informational and educational, to take into account multiple values of forests. Guidance, handbooks, trainings and other knowledge dissemination instruments can support permit holders to reforest the land in an environmentally sustainable way.

Thirdly, economic incentives contribute to the success of this measure. In Iceland the reference country - the restoration activities are mainly financed from the national funds, but also from industry (mainly energy companies) and are supported by the legislation on soil conservation (Hagen et al. 2013). The state of Iceland supports afforestation on farms and other privately owned land (Korsbakken \& Aamaas, 2016).

\subsubsection{Possible barriers}

Similarly to the Nordic countries, where the likely barriers for reforestation are alternative land uses with higher perceived economic value (Korsbakken \& Aamaas, 2016), food production, infrastructure or real estate development on deforested land can be preferred to reforestation in the target countries. On the other hand, former open-pit mines can be important habitats for several protected species who would not 
survive on forest land, e.g. natterjack toad (Epidalea calamita) or sand lizard (Lacerta agilis) (IUCN, 2017).

Reforestation needs knowledgeable planning to restore forest habitats to their original state and ensure that reforestation would not lead to the creation of monocultural forest plantations with negative impacts on biodiversity.

In general, the Baltic States and Poland are considered as relatively rich in forests. Ukraine, on the other hand, is an agro-industrial country where forest coverage is low and reforestation would help protect soil from further erosion. However, it must be ensured that reforestation does not take place on good agricultural lands.

Other problems to consider are the increasing wood cutting volumes in the target countries and illegal logging which takes place in some of the target countries (Illegal logging portal, 4.1.2018).

\subsubsection{Major co-benefits}

Reforestation of degraded lands contributes to major health and environmental benefits. The risks for soil erosion, floods and desertification of land would be mitigated. Roots of the trees reduce the negative effects of the nutrients leaching and improve the quality of the soil.

Also, the forest land will have higher recreational, biodiversity and economic value than the previously degraded land.

\subsubsection{Policy recommendations}

Given the above mentioned drivers of success in the benchmark country and the key enablers and barriers, the following policy recommendations are made:

- Improving the effectiveness of relevant government policies, including investment schemes and other support incentives, which would benefit the restoration of land by public and private landowners. Degraded land areas, including exhausted peat fields, should be prioritised;

- Considering introduction of payment for ecosystem services - monetary payments to landowners who maintain forests, which provide environmental services;

- Providing information on best forestry practices and their benefits;

- Strengthening enforcement of regulation for preventing illegal wood cutting. 


\subsection{Manure management}

\subsubsection{Description of the solution}

Greenhouse gas nitrous oxide $\left(\mathrm{N}_{2} \mathrm{O}\right)$ is generated through animal waste storage and treatment. Its emission level depends on the system and duration of manure management. Denmark has been successful in decreasing $\mathrm{N}_{2} \mathrm{O}$ emissions over recent decades.

This abatement solution is firstly about controlling how and when to spread manure and secondly about requirements for storage and use. In addition, various crops have standards related to fertiliser application amounts.

Hence, the degree of implementation for this solution is calculated as the decrease in emissions of $\mathrm{N}_{2} \mathrm{O}$ from agriculture. Denmark has been used as the benchmark. The scale-up and baseline assumptions are discussed in the following subsection.

\subsubsection{Scale-up method and baseline}

Following the benchmark case of Denmark, a 14.4\% decrease from the baseline is assumed also for 5 countries that are being analysed by year 2030. For the target countries, Eurostat and FAO (Ukraine) data were used to determine initial (2015) level of $\mathrm{N}_{2} \mathrm{O}$ emissions from manure management and agricultural soils (see table below). For all target countries, the baseline growth is, due to the lack of country specific information, based on the Estonian growth estimate (17\% from 2015-2030).

Table 24: $\mathrm{N}_{2} \mathrm{O}$ emissions from manure management and agricultural soils in the target countries (kt)

\begin{tabular}{|c|c|c|c|c|c|}
\hline & Estonia & Latvia & Lithuania & Poland & Ukraine \\
\hline $\begin{array}{l}\text { Manure } \\
\text { management }\end{array}$ & 0.21 & 0.34 & 0.80 & 6.37 & 9.78 \\
\hline Agricultural soils & 2.17 & 5.56 & 8.16 & 42.68 & 53.21 \\
\hline Total & 2.38 & 5.90 & 8.96 & 49.05 & 62.99 \\
\hline
\end{tabular}

Note: Data from 2015, except for Ukraine 2014.

\subsubsection{Net abatement potential}

In total, manure management has an abatement potential of $6 \mathrm{Mt} \mathrm{CO}_{2}$ eq (Table 23). Again, the largest contributions are from Poland (2 $\mathrm{Mt} \mathrm{CO}_{2}$ eq) and Ukraine $(3 \mathrm{Mt}$ $\left.\mathrm{CO}_{2} \mathrm{eq}\right)$. As for the relative shares, this solution has highest potential in Latvia and Lithuania where the abatement potential comprises about $3 \%$ of the country's projected GHG emissions in 2030. The share in the rest of the countries is slightly lower, remaining less than $1 \%$ of $2030 \mathrm{GHG}$ emissions. 
Table 25: The target countries' abatement potential in 2030 ( $\mathrm{Mt} \mathrm{CO}_{2} \mathrm{eq}$ and \% in 2030 emissions)

\begin{tabular}{lrr} 
Country & Mt $\mathrm{CO}_{2} \mathrm{eq}$ & $\begin{array}{r}\text { \% of 2030 emissions of } \\
\text { respective country }\end{array}$ \\
Estonia & 0.11 & 0.8 \\
Latvia & 0.28 & 2.8 \\
Lithuania & 0.43 & 2.5 \\
Poland & 2.33 & 0.6 \\
Ukraine & 2.99 & 0.4 \\
Total & 6.14 & \\
\hline
\end{tabular}

\subsubsection{Abatement costs}

Danish unit cost of $4.97 \mathrm{USD} / \mathrm{tCO}_{2}$ eq (2012 values), derived from Nordic model, was transformed to country specific EUR values by using PPP method (Eurostat). The weighted average unit abatement cost is provided in the following table.

Table 26: Abatement cost for manure management in 2030 (in 2017 EUR)

\subsubsection{Important enablers}

National and EU regulatory requirements on fertiliser and manure management, in particular water quality regulations, are driving more efficient manure management and mitigation of $\mathrm{N}_{2} \mathrm{O}$ emissions. For this purpose, collaboration of all relevant ministries and agencies and harmonisation of policies are crucial. Ukraine is also planning to adopt the legislation corresponding to the EU requirements in this sphere.

As the Danish experience has shown, general regulation can be useful in controlling widespread excessive applications of nitrogen. However, if further reductions are necessary, measures should be spatially targeted (Dalgaard et al. 2014).

Financial incentives can help farmers to invest in appropriate manure and fertiliser management, including storage and application. Collaboration between farmers to share manure storage and manure application equipment as well as the more targeted spreading of manure on appropriate fields can further facilitate manure management.

Systemic dissemination of knowledge is needed about improved management techniques and cost savings potential to farmers, such as 1) application timing, placement and amounts; 2) storage times and conditions; 3 ) manure export as well as 4) reducing the amount of manure nitrogen with dietary manipulation, breeding nitrogen efficient livestock, and livestock selection. 


\subsubsection{Possible barriers}

The barriers for improved manure management or the spreading, storage and use of manure and fertilizers to reduce the emissions of $\mathrm{N}_{2} \mathrm{O}$ are usually related to the lack of knowledge, motivation or resources. Manure has been undervalued as an important fertilizer and fuel. Also, there can be unwillingness of farmers to change their current manure management systems. In addition to general motivation, the lack of resources to invest in infrastructure and equipment is problematic especially for small producers for whom large investments would increase the cost of production in the short term.

Also, weak policy enforcement can be a barrier. In some cases monitoring compliance with regulations is complicated, for example, with how quickly and where manure is to be tilled into the soil.

\subsubsection{Major co-benefits}

The main environmental co-benefits as a result of reduced $\mathrm{N}_{2} \mathrm{O}$ emissions are the reduction of nitrogen leaching to the environment and improved groundwater quality. Socio-economic benefits from manure management as an abatement solution are related to drinking water health impacts (Dalgaard et al. 2014). Also, sound manure management practices can optimise the use of nutrients in manure for soil fertilisation, improve general waste management and lead to lower costs for the water purification. A reduction of fertiliser consumption would reduce the costs for farmers.

Manure management creates opportunities for renewable energy generation - the process of anaerobic treatment of manure, sludge and green biomass yields in biogas and nutrient-rich digestate. Biogas can be used either in boiler house to produce heat or upgraded to biomethane for transport fuel. Digestate can be used as a valuable fertiliser - no nutrients are lost during the digestion process itself and the total nutrient content in the digestate equals to nutrient content of biomass.

\subsubsection{Policy recommendations}

Given the above mentioned drivers of success in the benchmark country and the key enablers and barriers, the following policy recommendations are made:

- Financial incentives to support investments into manure storages and anaerobic digestion of sludge for producing biogas;

- Promotion of biomethane consumption in transport as a domestic renewable fuel (e.g. tax exemption (VAT) to introduce biomethane as a fuel to market);

- Providing information on best farming practices and their benefits;

- Strengthening enforcement of manure management regulation. 


\section{Discussion of the results}

There are several issues related to the cost figures utilised. The exact cost number projected by 2030 is dependent on several factors and drivers, which we were not able to calculate very precisely on individual country basis in this study. In addition, some of the cost figures are more dependent on local circumstances rather than global technology. For the sake of consistency and comparability, we have used the same mentioned approach as in earlier Green to Scale studies. This means that the cost figures presented for solutions cannot be treated as very exact price tags, but rather rough estimations of magnitude. The cost figures are not covering the societal cost of different indirect effects, for example health benefits, competition for land or biodiversity issues. These are addressed in qualitative analysis of the solutions.

The results are dependent on information that is available, and there are several issues that need to be raised. As the projections are for 2030, these are the best estimates done by experts in a field, but still the reality might be something else, as technologies are developing really fast. Furthermore, the countries under study are still in development in different ways. Changes in lifestyles, consumption patterns, industrial structure etc. are still evolving, having implications on future consumption and production patterns perhaps more strongly than is the case of Nordic developed countries.

To have consistent results, we have tried to use the same sources about baselines where possible (for example, EU Reference scenario for Estonia, Latvia, Lithuania and Poland). However, we cannot use the same source for Ukraine, and also in case of other data, Ukraine was the biggest challenge for obtaining data.

For the $\mathrm{CO}_{2}$ intensity of electricity generation by 2030, we have used the regional average, as country-level projections were unavailable in comparable manner. The average $\mathrm{CO}_{2}$ intensity of electricity generation for Eastern Europe in 2030 is projected to be $0.607 \mathrm{Mt} \mathrm{CO}_{2}$ eq/TWh (IEA, 2015). As of now, carbon intensity of electricity generation is higher than this level in Estonia and Poland and lower in Latvia, Lithuania and Ukraine. Consequently, this study might overestimate abatement potential for Latvia, Lithuania and Ukraine and underestimate for Estonia and Poland, but only if the current national energy mixes and technologies will not change much. However, the electricity market is being integrated in these countries, which means that e.g. building more wind power in Latvia can contribute to reducing GHG emissions from electricity use in Estonia. Several policy measures which increase the share of renewable energy are already in place. Results from the BENTE study indicate that in the Baltic countries, overall electricity generation mix might have lower $\mathrm{CO}_{2}$ intensity by 2030 than estimated in this study (BENTE, 2018), but comparable analysis in not available for Poland and Ukraine. Hence, for the sake of comparability, the regional average projection by IEA is the best available estimate. The abatement potential also does not 
include the extension of biomass use on competition for agricultural land and the net climate impact, but these concerns are pointed out.

Biomass sustainability is one of the key issues in scaling up the bioenergy-related climate solutions, as biomass must be produced in a sustainable way in order to reduce greenhouse gas emissions. At the same time growing demand for biomass in bioenergy and in other branches of bioeconomy will increase the competition for natural resources, in particular for land and water resources with potential negative impact on the land use patterns, biodiversity and environment. The contribution of biomass to energy generation in the EU will further increase as a result of the renewable energy targets. While so far biofuels are largely produced in Europe from food crops (sugar and starch crops for bioethanol and oil crops for biodiesel), the production of the second generation lignocellulosic biofuels should increase (Scarlat et al. 2015). The limited availability of sustainable biomass requires cascading use of biomass, according to which the usage of waste products are only allowed for energy recovery, when there are no other options for alternative uses with more value added for the society. Energy recovery is generally the last option for using resources.

The European Commission's proposal for LULUCF regulation for the period of 2021-2030 will probably limit the use of wood as a source of renewable energy. The sustainability criteria in the proposal for renewable energy directive are expected to guarantee real carbon savings and protect biodiversity. There are also plans to introduce with the proposal the verification of sustainability of wood chips in domestic use, in addition to exporters of pellets and wood chips.

In case of the policy recommendations, in many solutions these were similar for the Baltic states and Poland and therefore presented together. For Ukraine, which is not an EU member state, some specific recommendations could be made. These recommendations are the first step and can be used as a basis for the development of more country-specific proposals.

It was not feasible to give a solid estimation with high degree of confidence on the possible extent of overlaps of abatement impact of solutions targeting partly the same sources of emissions. The analysis focused on 5 countries with varying starting points and having possibilities ranging from each country choosing either to scale only one to scaling all 10 solutions to maximum degree. Some are solutions that can be viewed as alternative, some are solutions that can both be implemented. Also, in some countries one of the overlapping solutions is not relevant (like CHP and biomass in district heating), because either one is already above the benchmark level. 


\section{References}

Antonenko, A.; Nitsovych, R.; Pavlenko, O.; Takac, K. (2018). Reforming Ukraine's Energy Sector: Critical Unfinished Business. Carnegie Europe. http://carnegieeurope.eu/2018/02/06/reformingukraine-s-energy-sector-critical-unfinished-business-pub-75449

Bauwens, T.; Gotchev, B.; Holstenkamp, L. (2016). What drives the development of community energy in Europe? The case of wind power cooperatives. Energy Research \& Social Science 13: 136-147.

Beltman, B. J.; Hendriks, C.; Tum, M.; Schaap, M. (2013). The impact of large scale biomass production on ozone air pollution in Europe. Atmospheric Environment 71: 352-363.

BENTE (2018). Baltic Energy Technology Scenarios 2018. Targeting low carbon and renewable energy systems. Final draft report as of January 2018.

Brack, D. (2017). Woody Biomass for Power and Heat Impacts on the Global Climate. Research Paper. Chatham House, Royal Institute of International Affairs. February 2017.

Cambridge Econometrics (2015). Assessing the Employment and Social Impact of Energy Efficiency. Final report, Volume 1: Main report, November 2015.

https://ec.europa.eu/energy/sites/ener/files/documents/CE_EE_Jobs_main\%2018Nov2015.pdf Carragher, V.; McLoughlin, P. J.; Kenny, P. (2013). The Job Creation Prospects of Renewable and Sustainable Energy Technologies. http://tippenergy.ie/wp-content/uploads/2013/o7/Carragheret-al-2013.pdf

Castillo, C. P.; Silv, F. B.; Lavalle, C. (2016). An assessment of the regional potential for solar power generation in EU-28. Energy Policy 88: 86-99.

Dalgaard, T.; Hansen, B.; Hasler, B.; Hertel, O.; Hutchings, N. J., Jacobsen, B. H.; Stoumann Jensen, L.; Kronvang, B.; Olesen, J. E.; Schjørring, J. K. (2014). Policies for agricultural nitrogen management - trends, challenges and prospects for improved efficiency in Denmark. Environ. Res. Lett. 9115002.

Danish Energy Agency (2018). The Danish Energy Model https://ens.dk/sites/ens.dk/files/contents/material/file/the_danish_energy_model.pdf

EAFO (European Alternative Fuels Observatory) (2018). Countries. http://www.eafo.eu (accessed 15.2.2018).

Ecofys (2015). The potential of scaling up proven low-carbon solutions. Final report. ECOFYS Germany $\mathrm{GmbH}$.

ENMAK 2030 + (2017). Estonian National Development Plan of the Energy Sector.

EREA (Estonian Renewable Energy Association). (2017). Renewable Energy Yearbook 2016.

Ericsson, K. \& Werner, S. (2016). The introduction and expansion of biomass use in Swedish district heating systems. Biomass and Bioenergy 94: 57-65.

Estonian National Inventory Report (2017). Greenhouse Gas Emissions in Estonia 1990-2015. Submission to the European Commission.

http://unfccc.int/national_reports/annex_i_ghg_inventories/national_inventories_submissions /items/10116.php

Estonian Road Administration (2017). www.mnt.ee

Euroheat \& Power (2017). Country profiles. https://www.euroheat.org/knowledgecentre/country-profiles/ (accessed 13.2.2018).

European Commission (2016). EU Reference Scenario 2016. Energy, transport and GHG emissions. Trends to 2050.

European Environment Agency (2009). Europe's onshore and offshore wind energy potential. 
European Environment Agency (2017). EEA database on climate change mitigation policies and measures in Europe. http://pam.apps.eea.europa.eu

Eurostat (2017). Database. http://ec.europa.eu/eurostat

EV Norway (2017). Norwegian EV market. http://elbil.no/english/norwegian-ev-market/

Factor $\mathrm{CO}_{2}$ (2011). 2050: Greenhouse Gas emissions projections for Ukraine. Prepared for EBRD.

Finnish Energy (2018). Combined heat and power generation.

https://energia.fi/en/energy_sector_in_finland/energy_production/combined_heat_and_powe r_generation

Fraunhofer ISE (2015). Current and Future Cost of Photovoltaics. Long-term Scenarios for Market Development, System Prices and LCOE of Utility-Scale PV Systems. Study on behalf of Agora Energiewende.

Fraunhofer ISE (2017). Recent Facts about Photovoltaics in Germany.

Fraunhofer ISE (2018). Recent Facts about Photovoltaics in Germany.

Greenpeace, EREC (2011). The advanced energy [r]evolution. A sustainable energy outlookfor Sweden.

Hagen, D.; Svavarsdottir, K.; Nilsson, C.; Tolvanen, A. K.; Raulund-Rasmussen, K.; Aradóttir, Á. L.; Fosaa, A..; Halldorsson, G. (2013). Ecological and social dimensions of ecosystem restoration in the Nordic countries. Ecology and Society 18(4): 34 .

Haugneland, P.; Lorentzen, E.; Bu, C.; Hauge, E. (2017). Put a price on carbon to fund EV incentives - Norwegian EV policy success. EVSzo Symposium, Stuttgart, Germany, October 911, 2017.

Herbes, C.; Brummer, V.; Rognli, J.; Blazejewski, S.; Gericke, N. (2017). Responding to policy change: New business models for renewable energy cooperatives - Barriers perceived by cooperatives' members. Energy Policy 109: 82-95.

Iceland's Sixth National Communication and First Biennial Report (2014). Under the UNFCCC. http://unfccc.int/national_reports/national_communications_and_biennial_reports/submissio ns/items/7742.php

IEA (International Energy Agency) (2017). www.iea.org

IEA (International Energy Agency) (2015). World Energy Outlook.

IEA Bioenergy (2012). Future Biomass-based Transport Fuels. Summary and Conclusions from the IEA Bioenergy ExCo67 Workshop. IEA Bioenergy:ExCo:2012:02.

IFC (International Finance Corporation) (2015). Market Conditions for Biomass-to-Energy Projects in Ukraine. Survey Findings. World Bank Group.

Illegal Logging Portal, http://www.illegal-logging.info/ (accessed 4.1.2018).

INDC of Ukraine (2015).

http://www4.unfccc.int/Submissions/INDC/Published\%20Documents/Ukraine/1/150930_Ukrai ne_INDC.pdf

Interfax Ukraine (2018). Energy Efficiency Fund begins its work in Ukraine. http://en.interfax.com.ua/news/economic/474230.html (accessed 2.1.2018).

IRENA (2018). Renewable Power Generation Costs in 2017. International Renewable Energy Agency (IRENA), Abu Dhabi. January 2018.

IRENA (2017). Renewable Capacity Statistics 2017. International Renewable Energy Agency (IRENA), Abu Dhabi. March 2017.

IRENA (2015a). REmap 2030. Renewable energy prospects for Poland. International Renewable Energy Agency (IRENA), Abu Dhabi. October 2015.

IRENA (2015b). REmap 2030. Renewable energy prospects for Ukraine. International Renewable Energy Agency (IRENA), Abu Dhabi. April 2015.

IUCN (2017). The IUCN Red List of Threatened Species 2017-3. Lacerta agilis. Epidalea calamita. (accessed 28.2.2018).

Korsbakken, J., \& Aamaas, B. (2016). Technical report: Nordic Green to Scale. 
Krysiński, D.; Nowakowski, P.; Dana, P. (2017). Social Acceptance for Energy Efficient Solutions in Renovation Processes. MDPI Proceedings 1, 689; doi:10.339o/proceedings1070689.

Latvia's National Inventory Report (2017). Submission under UNFCCC and the Kyoto Protocol. http://unfccc.int/national_reports/annex_i_ghg_inventories/national_inventories_submissions /items/10116.php

LIAA (Investment and Development Agency of Latvia) (2015). Environment and Renewable Energy Industry in Latvia.

Lithuania's National Inventory Report. (2017). Greenhouse Gas Emissions 1990-2015. Submission under UNFCCC and the Kyoto Protocol.

http://unfccc.int/national_reports/annex_i_ghg_inventories/national_inventories_submissions /items/10116.php

McKinsey \& Company (2009). Pathways to a Low-Carbon Economy. Version 2 of the Global Greenhouse Gas Abatement Cost Curve.

Ministry of Foreign Affairs of Ukraine. About Ukraine. http://mfa.gov.ua/en/aboutukraine/info/general-facts (accessed 9.2.2018).

MURE Database (2018). http://www.measures-odyssee-mure.eu (accessed 5.2.2018).

Nabuurs, G.; Masera, O.; Andrasko, K.; Benitez-Ponce, P.; Boer, R.; ...; Zhang, X. (2007). Forestry. In B. Metz, O. Davidson, P. Bosch, R. Dave, \& M. L.A. Climate Change 2007: Mitigation. Contribution of Working Group III to the Fourth Assessment Report of the Intergovernmental Panel on Climate Change.

Nagevičius, M. (2017). Enabling conditions for renewable energy. Case of Lithuania. Presentation at the Second Preparatory Meeting for the 25th OSCE Economic and Environmental Forum, 15 June 2017.

OECD/IEA (2017). Global EV Outlook 2017. International Energy Agency, Clean Energy Ministerial, Electric Vehicles Initiative.

OECD/IEA (2013). The IEA CHP and DHC Collaborative. CHP/DHC Country Scorecard: Finland. International Energy Agency Insights Series 2013.

Pikas, E.; Kurnitski, J.; Liias, R.; Thalfeldt, M. (2015). Quantification of economic benefits of renovation of apartment buildings as a basis for cost optimal 2030 energy efficiency strategies. Energy and Buildings 86: 151-160.

Poland's National Inventory Report (2017). Greenhouse Gas Inventory for 1988-2015. Submission under the UNFCCC and its Kyoto Protocol.

http://unfccc.int/national_reports/annex_i_ghg_inventories/national_inventories_submissions /items/10116.php

Radavičius, A. (2017). Wind energy potential in Lithuania: opportunities and challenges. Presentation 20 Oct. 2017. Lithuanian Wind Power Association.

REN21 (2017). Renewables 2017 Global Status Report. Renewable Energy Policy Network, REN21 Secretariat for the 21st Century, Paris.

Rowe, R.L.; Street, N.; Taylor G. (2009). Identifying potential environmental impacts of largescale deployment of dedicated bioenergy crops in the UK. Renewable and Sustainable Energy Reviews 13(1): 271-290.

Scarlat, N.; Dallemand, J.-F.; Monforti-Ferrario, F.; Nita, V. (2015). The role of biomass and bioenergy in a future bioeconomy: Policies and facts. Environmental Development 15: 3-34.

SEI Tallinn (2016). National reports on energy efficiency policy scenario analysis for the residential and transport sectors. D.4.1. HERON Project.

Sims, R.; Schaeffer, R.; Creutzig, F.; Cruz-Nunez, X.; D'Agosto, M.; Dimitriu, D.; ... Tiwari, G. (2014). Transport. In O. Edenhofer, R. Pichs-Madruga, Y. Sokona, E. Farahani, S. Kadner, K. Seyboth, A. Adler, I. Baum, S. Brunner, P. Eickemeier, B. Kriemann, J. Savolainen, S. Schlömer, C. v. Stechow, T. Zwickel; \& J. C. Minx (Eds.), Climate Change 2014: Mitigation of Climate Change. Contribution of Working Group III to the Fifth Assessment Report of the Intergovernmental Panel on Climate Change. Cambridge, United Kingdom and New York, NY, USA: Cambridge University Press. 
Statistics Finland (2017). Renewable sources produced 45 per cent of electricity and 57 percent of heat. https://tilastokeskus.fi/til/salatuo/2016/salatuo_2016_2017-11-02_tie_001_en.html

Statistics Norway (2017). Registered vehicles. https://www.ssb.no/en/transport-ogreiseliv/statistikker/bilreg

Submission by Latvia and the European Commission on behalf of the European Union and its Member States (2015). Intended Nationally Determined Contribution of the EU and its Member States. http://www4.unfccc.int/Submissions/INDC/Published\%20Documents/Latvia/1/LV-03o6-EU\%2olNDC.pdf

The Polish Wind Energy Association (2017). The State of Wind Energy in Poland in 2016.

Timilsina, G. R.; Hochman, G.; Fedets, I. (2016). Understanding energy efficiency barriers in Ukraine: Insights from a survey of commercial and industrial firms. Energy 106: 203-211.

UCS (Union of Concerned Scientists) (2017). Benefits of Renewable Energy Use. http://www.ucsusa.org/clean-energy/renewable-energy/public-benefits-of-renewable-power (accessed 12.2.2018).

Ukraine's Greenhouse Gas Inventory 1990-2015 (2017). Submission under the UNFCCC and its Kyoto Protocol.

http://unfccc.int/national_reports/annex_i_ghg_inventories/national_inventories_submissions /items/10116.php

UNFCCC (2018). GHG data from UNFCCC. http://di.unfccc.int/time_series

USDA Foreign Agricultural Service (2017). EU Biofuels Annual 2017. Global Agricultural Information Network, 6/21/2017.

USDA Foreign Agricultural Service (2016). Lithuania - Biofuel Market Outlook 2016. Biofuels Market Outlook in Latvia 2016. Global Agricultural Information Network.

https://gain.fas.usda.gov

UWEA (Ukrainian Wind Energy Association) (2017). Ukrainian Wind Power Sector 2016.

WindEurope (2017a). Wind in power: 2016 European statistics. February 2017.

WindEurope (2017b). Wind energy in Europe: Outlook to 2020. September 2017.

Wiser, R.; Jenni, K.; Seel, J.; Baker, E.; Hand, M.; Lantz, E.; Smith, A. (2016). Forecasting Wind Energy Costs and Cost Drivers: the Views of the World's Leading Experts. IEA Wind Task 26.

World Bank (2018). World Bank Open Data. https://data.worldbank.org/ 


\section{Exekutiv sammanfattning}

I projektet Nordic Green to Scale 2 (NGtS2) analyseras möjligheten att skala upp befintliga klimatlösningar i två regioner; de baltiska länderna, Polen och Ukraina i Europa samt Kenya och Etiopien i Östafrika. I den här rapporten återges undersökningens resultat med avseende på de fem europeiska länderna (Estland, Lettland, Litauen, Polen och Ukraina). Tio olika lösningar valdes ut bland dem som ingick i de två tidigare undersökningarna - Green to Scale ${ }^{6}$ och Nordic Green to Scale - som särskilt lovande för regionen i fråga.

Analysen innefattar potentialen för utsläppsminskning, kostnader och besparingar samt sidovinster från att de utvalda lösningarna skalas upp. Dessutom granskar undersökningen de landsspecifika omständigheterna för tillämpning av lösningarna, inklusive utfärdande av policyrekommendationer som skräddarsys för behovet i de länder åtgärderna riktas mot.

Potentialen för utsläppsminskning varierar stort enligt lösning och land, eftersom de länder som undersöktes är olika stora, har olika ekonomiska strukturer och befinner sig på olika utvecklingsnivåer. Om lösningarna tillämpas tillsammans blir potentialen för utsläppsminskning 149 miljoner ton koldioxidekvivalenter $\left(\mathrm{CO}_{2 \mathrm{e}}\right)$, vilket utgör 13 procent av den utvalda regionens utsläpp av växthusgaser fram till 2030. I absoluta tal gäller den högsta potentialen för utsläppsminskning energieffektivitet $i$ byggnader och industri ( 53 miljoner ton $\mathrm{CO}_{2}$ respektive 25 miljoner ton $\mathrm{CO}_{2 \mathrm{e}}$ ). Den högsta potentialen för utsläppsminskning enligt sektor gäller byggnads- och hushållssektorn, genom energieffektiveringsåtgärder och att bioenergi används för uppvärmning (67 miljoner ton $\mathrm{CO}_{2 \mathrm{e}}$ ). Därefter följer lösningarna inom energisektorn, främst till följd av potentialen för utsläppsminskning inom utvecklingen av vind- och solenergi på land (41 miljoner ton $\mathrm{CO}_{2 \mathrm{e}}$ ).

De lösningar som har störst minskningspotential är också de som är mest kostnadseffektiva, eftersom deras totala kostnad är negativ - energieffektivitet i fråga om byggnader skulle medföra nettobesparingar på -2,9 miljarder euro medan energieffektivitet inom industrin skulle innebära nettobesparingar på -0,5 miljarder euro fram till 2030. Enhetskostnaden för förbättrad energieffektivitet i byggnader skulle bli -54 euro per ton $\mathrm{CO}_{2 e}$ och -18 euro per ton $\mathrm{CO}_{2 e}$ för förbättrad energieffektivitet i byggnader. Kostnaderna blir högst för användningen av bioenergi för uppvärmning (1 miljard euro), vindkraft på land (0,5 miljarder euro) och solenergi $(0,4$ miljarder euro).

\footnotetext{
${ }^{6}$ Ecofys 2015 Sitra. Afanador, A., Begemann, E. Bourgault, C., Krabbe, O. Wouters, K. The potential of scaling up proven low-carbon solutions. Final report, 5 November 2015.

7 Korsbakken, J. I., Aamaas, B. 2016 Technical report: Nordic Green to Scale.
} 
Även om den största minskningspotentialen för de flesta av lösningarna i absoluta tal gäller Polen och Ukraina, medför en uppskalning av dessa lösningar i Estland, Lettland och Litauen betydligt större effekt i relativa termer. Alla målländerna har goda naturresurser för utveckling av vind- och solenergi samt bioenergi. I medlemsstaterna i Europeiska unionen (EU) är EU:s mål, regelverk och ekonomiska stöd av stor vikt för att möjliggöra uppskalningen av lösningarna. För Ukrainas del syftar internationella konventioner och stödprogram, inklusive EU-avtal och program, till att främja en liknande gynnsam miljö. Den pågående globala nedgången i priset på förnybara energitekniker sporrar alltfler utvecklare och konsumenter till att använda sig av förnybara energiresurser. De främsta hindren för att lösningarna ska införas i stor skala är policyer som gynnar ekonomier baserade på fossila bränslen samt osäkerhet avseende hur marknaden och lagstiftningen utvecklas. 


\section{Annex. List of interviewees and focus group participants}

Estonia:

- Mr Siim Meeliste, Ministry of Economic Affairs and Communications.

Latvia:

- Mr Gaidis Klāvs, Institute of Physical Energetics.

- Mr Ivars Kurdenickis, University of Latvia.

- Ms Andžela Pētersone, Ministry of Economics.

Lithuania:

- Mr Arvydas Galinis, Lithuanian Energy Institute.

- Dr Ramūnas Gatautis, Lithuanian Energy Institute.

- Dr Vaclovas Miškinis, Lithuanian Energy Institute.

- Mr Daumantas Kerežis, Ministry of Energy.

- Mr Tadas Navickas, 4energia UAB, Lithuania.

Poland:

- Mr Waldemar Lagoda, Ministry of Economy, Poland.

- Mr Gerard Lipiński, the National Centre for Research and Development, Poland.

Ukraine:

- Mr Vasyl Vovchak, Institute for Environment and Energy Conservation, Ukraine.

- Mr Oleksandr Teslenko, Global Design Institute.

- Mr Mykola Politykin, Misto-Energy Ltd.

- Ms Inna Sushkova, Environmental Alliance, Vin-Pellet Ltd.

- Ms Elena Filonova, Institute for Environment and Energy Conservation.

- Mr lyevgen Koteltsov, Institute for Environment and Energy Conservation.

- Mr Oleksii Samchenko, USAID project "Municipal Energy Reform in Ukraine". 
Nordic Council of Ministers

Nordens Hus

Ved Stranden 18

DK-1061 Copenhagen K

www.norden.org

Technical report: Nordic Green to Scale for countries

This technical analysis for the Nordic Green to Scale for countries report was commissioned to Stockholm Environment Institute (SEI) Tallinn Centre. The project zooms in on two regions: the Baltic States, Poland and Ukraine in Europe; and Kenya and Ethiopia in East Africa. This report presents the emission reduction potential of 10 selected solutions for the European target countries. The study highlights the costs, savings and co-benefits of implementing the solutions as well as makes policy recommendations for capturing the potential. The project was carried out by the Finnish Innovation Fund Sitra, together with its partners CICERO, CONCITO and Institute of Sustainability Studies at the University of Iceland. The technical analysis was produced by the Stockholm Environment Institute Tallinn Centre. The project is part of the Nordic Council of Ministers' Prime Ministers' Initiative. 